\title{
CYTOLOGICAL OBSERVATIONS ON THE BEHAVIOR OF CHICKEN BONE MARROW IN PLASMA MEDIUM ${ }^{1}$
}

\author{
RHODA ERDMANN
}

Osborn Zoological Laboratory, Yale University, New Haven, Connecticut, and Rockefeller Institute for Medical Research, Department of Animal

Pathology, Princeton, New Jersey

TWO TEXT FIGURES AND NINE PLATES

The writer, employing the bone marrow of the chicken for attenuating the virus of cyanolophia (Erdmann ' $16^{2}$ ), by culture of the marrow and the virus in a medium of chicken plasma, has observed some interesting facts concerning the cytological changes in the bone marrow cells.

The morphology and development of chicken bone marrow and its relation to blood formation have been described by few authors. Dantschakoff ('09, pp. 859-65) gives an extensive review of the literature on these questions and establishes our knowledge of the origin of the different elements of chicken bone marrow.

In studying the cells of bone marrow in plasma culture medium, we must take into consideration the fact, that we add to the plasma in which the tissue culture is cultivated a heterogeneous mixture of highly differentiated cells. Chicken bone marrow has a loose framework of slender connective tissue cells, in the meshes of which blood and fat cells are scattered. The blood cells-eosinophils, erythrocytes, and myelocytesform, according to Foot ('13, p. 45) strands and circles between and around the fat cells. The blood islands represent collections of cells of microlymphocytic and macrolymphocytic types, of more or less ripe erythrocytes and of young connective tissue cells. It must be clearly kept in mind that all these different

${ }^{1}$ Received for publication March 14, 1917.

${ }^{2}$ Erdmann, Rh. 1916 Attenuation of the living agents of cyanolophia, Proceedings of the Society for Experimental Biology and Medicine, vol. 8, pp. 189-193. 
elements behave differently in the tissue cultures and may, after having undergone important changes in the plasma, offer some difficulties in interpretation.

The only observations of normal chicken bone marrow in plasma are those made by Foot ' 12 and ' 13 . In the first series of experiments he studied especially the behavior of the fatty elements of chicken bone marrow, recording the following results. Six hours after implantation numerous cells leave the tissue center. They form rays of cells liquefying the plasma. These rays are formed by polymorphous leucocytes with eosinophile granules and by "eine Art von mononukleären basophilen Zellen" (p. 450). Foot gives the latter the name of $\mathrm{X}$ cells; they are the most important and they contain only fat according to his observations of 1912. They form, he says in 1912, the bulk of all cells migrating into the surrounding plasma. These $\mathrm{X}$ cells, the origin of which Foot tries to elucidate, are true phagocytes They include small fatty droplets and other particles which are dispersed in the cytoplasm. On the fourth day, these cells, after having been enlarged by the amount of fat which they have taken up during the first three days in the culture, form either syncytial masses or a widely spread network of anastomosing cells. The former may divide, after having lost most of their fatty granules, and form the final 'ruhende X Zelle' (Foot '12, fig. 8, pl. 22): or the latter, after having been highly vacuolized, as stated by Foot ' 12 , may form fibrils (fig. 18, pl. 22). If these $\mathrm{X}$ cells do not form resting $\mathrm{X}$ cells or cells which produce fibrils, they take the shape of 'Riesenzellen.' These 'Riesenzellen' are not identical, in Foot's opinion, with the 'giant' cells of the normal bone marrow. They are represented in his figures $11,16,17,19$. They are only $\mathrm{X}$ cells which have fused together, form no fibrils, and may later break up in small cells (figs. 12 to 14 ), which have generally one nucleus. "Das Ergebnis der Aufteilung der Riesenzellen ist sozusagen eine neue Zellrasse" (p. 460) - cells adapted to the condition of the medium.

Foot believes that the $\mathrm{X}$ cells are transformed cells of the 'mesenchyme' and ' Zwar indifferent gewordene Mesenchymzel- 
len" (p. 466). He reasons as follows: Because these cells have the potentiality of forming fibrils they must belong to those cells which can form connective tissue, and therefore these $\mathrm{X}$ cells without any intermediate stages take their origin from mesenchymal or endothelial cells. In a postscript to this paper he changes his opinion entirely and says (p. 475): "Was die Herkunft der X Zellen betrifft, so scheint es als ob die Hauptmasse derselben entweder direkt oder indirekt von den lymphocytären oder myeloblastischen Elementen des Knochenmarkes abstammte," promising to give the reasons for this change of opinion in his second communication.

After a careful study of Foot's second publication ('13), which is rather difficult to understand because he does not very often connect his first publication with the second, I restate in his own words his revised opinion of the origin of those cells which form X cells ('13, pp. 46-47). "The deductions as to the transformation of the lymphocytes from one form to another, which form the basis of the following descriptions, were made from the observation of transition forms. The later transformations of these cells into forms resembling fat and giant cells or cells of the connective tissue have been considered in my previous article." So it appears that the so-called X cells of this author ('12)- the name does not often appear in the paper of 1913-are not directly transformed cells of the mesenchymal type but are said to be of lymphocytic origin. He observes that as early as three hours after implantation of the bone marrow a considerable number of microlymphocytes emigrate from the tissue particle. Their transformation occurs in the following way:

The small microlymphocytes are first transformed into macrolymphocytes, later into large mononuclear forms, then into myelocytes. At last the polymorphonuclear leucocytes appear, after having undergone different changes in the form and structure of the nucleus. The nucleus is at first horseshoe-shaped, later polymorphonuclear and even polynuclear. Finally the cells, by rounding off and dechromatization of the nucleus coincident with the rarification and a change in the staining 
properties of the plasma, are transformed into the cell culture type (p. 56). This cell culture type (see his fig. 2, pl. 3, and his fig. 3 , pl. 4) represents small polymorphonuclear leucocytes (p. 49) which have undergone the transformation, but not only does the cell culture type originate from lymphocyte forms, but this 'stem cell' can also be transformed through the transition stage of amoeboid forms into 'giant cells,' syncytia, and, as said before, into the cell culture type (table 1, p. 56).

Thus it is clear that, according to this author's view, all the different forms described by Foot in 1912 and 1913 originate from the microlymphocytes. Until the present time ('16) this important fact lacked verification, but by the cultivation of the virus of cyanolophia in chicken bone marrow an opportunity was afforded of observing the changes which Foot describes. A careful study of the morphological and cytological characters of the cells figured in the above mentioned papers, soon showed a lack of transition stages, which are needed as proof of Foot's final theory. Further, the nuclei of cell forms which are said to be transformed into each other do not show close resemblances, e.g., the cells in figures 1 and 3, 1913, which are said to be eosinophil leucocytes at different stages of incubation, have different nuclear structure as well from each other and from the cell of the cell culture type (fig. 2, left side, 1913). The nuclear structure of this particular cell (fig. 2, left side, 1913), however, has a certain resemblance to the nuclei shown in 1912, figures 5 and 6 . These cells are considered by Foot as stages connecting the 'Riesenzellen' with "eine Art von monnukleären basophilen Zellen" (1912, p. 450). But here, as far as could be judged from the drawings, the cytoplasm of the cells in figures 5 and 6 is very different. Figure 5 has granules, figure 6 does not show them; only traces of digested nuclei of other cells are visible. These contradictory facts present a priori difficulties in accepting the views of Foot. But they appeared far more disconcerting on examining the cells themselves. 
TECHNIQUE OF CULTIVATING, PRESERVING, AND STAINING BONE MARROW

It is not necessary to describe in detail the technique of these cultures, since the writer followed the same methods as those used by Harrison ('10), Burrows ('11), and particularly Foot ('12 and '13). For storing the plasma it was deemed important to use the methods described by Walton ('12) for keeping mammalian plasma in good condition for long periods of time. Great stress was laid on the study of the living cells, and a warm stage was used to follow out the transitions of one cell form into another. The bone marrow of very young chickens, those of medium age, and of old individuals was studied; observations were also made on bone marrow which contained a very small amount of fat, as well as that which had a large amount of fat.

The method described below gave the best results in identifying and showing the stages of the individual cell types in stained preparations. A small particle of bone marrow was put into the plasma medium. The cells in the tissue were then allowed to migrate out of it. At periods of either 2, 4, 6, 12, or 24 hours, the original particle of bone marrow was extracted, and the fate of those cells which had emigrated was studied. The writer found that from the original particle of tissue numerous cellforms had been sent into the surrounding plasma clot. Having thus extracted the bone marrow, it could be determined with absolute exactitude which cell-forms emigrated first, and the history of those cell types which had emigrated after 2, 4, 6, 12, or 24 hours, or at any given period, could be recorded. The extracted particle of bone marrow was now transferred to a new plasma medium and the cell forms which emigrated after the transfer were also observed. This was repeated several times, until practically all emigration of cells into the surrounding plasma had ceased. The structure of the remaining particle of bone marrow was of course studied. Smears and sections were made at every stage of the emigration process and a more complete history of this complicated process was thus obtained.

In staining the pieces of bone marrow, the methods used by Foot in 1912 and 1913 were followed and other methods for the 
discovery of fat were added (see descriptions of plates, page 118 . Besides these, the Giemsa stain after moist fixation according to the prescription of Giemsa proved to be very satisfactory. No dry smears of bone marrow were used.

\section{THE FATE OF LIVING BONE MARROW CELLS IMPLANTED IN PLASMA AT $38^{\circ} \mathrm{C}$.}

The experiments from which the drawings on plates 1 and 2 were made were started on December 25, 1915, and on January 3,1916 . The bone marrow was taken from a full-grown chicken which had a large amount of fat, so that the pieces of marrow have a yellowish-white appearance. The first cells to leave the tissue after 40, 60, and 90 minutes incubation are, as Foot rightly remarks in his publication of 1913 (p. 49), small mononuclear or larger polymorphonuclear leucocytes (fig. 1). The forms have a very dark, granulated cytoplasm and are actively amoeboid (fig. 1). Pale mononuclear forms without granulations but with their characteristic vesicular nucleus, follow closely the emigrating polymorphonuclear leucocytes. The fourth cell from the left (fig. 1) represents an erythroblast. The structure of the nucleus makes this evident. Besides these forms figured in figure 1, red blood corpuscles and a few fat cells were present in those parts of the plasma clot which surround the implanted bone marrow particle. The network of the bone marrow was injured by the process of cutting and tearing the particle into small pieces, and it is therefore not surprising that a large number of red blood corpuscles and some fat cells were scattered into the surrounding plasma clot. They are not figured in figure 1.

After 24 hours various other cell types have migrated into the surrounding plasma.

Figure 2 shows bone marrow which has been in the plasma for 24 hours, from January 3 to January 4, 1916. We can easily distinguish two different kinds of granulocytes: big cells which have round, shining granules, the nucleus nearly half as big as the cell and half-moon shaped; and smaller forms, with very dark granules, the latter not rounded but more rod-shaped, the 
nuclei spherical and very often dividing. It is impossible to define without doubt the exact type of these granulocytes before the relation of their granules to basic or acid stains develops the true character of these cells. Therefore we do not venture any interpretation of the bigger type of these granulocytes but point out only that the smaller forms must be eosinophil leucocytes after their morphological structure, though their granules appear rather darker than those in non-incubated leucocytes of chicken-bone marrow. Also they have less distinctly round or less rod-shaped granules. These two observations are important. The big cell in the center of the figure 2 does not contain any granules but is from the large nongranular mononuclear lymphocyte type. Very often these cells break into pieces during observation.

Two other cells, one on the right, the other on the left side of figure 2 are of a different type. They contain large shining droplets, the fatty nature of which seems doubtless. Their nuclei have a vesicular structure and appear at this stage of the culture as often dividing. They are less numerous than the eosinophil leucocytes which form, in the first 24 hours, the bulk of all cells migrating into the surrounding plasma medium.

Figure 3 represents bone marrow which has been incubated for 48 hours (January 3 to January 5, 1916). Here a 'Riesenzelle' is rapidly moving; its. cytoplasm is spread over a great area on the cover-glass and contains fat droplets and glistening granules. This 'Riesenzelle' shows in its cytoplasmic structure a close resemblance to the fat droplet containing cells on figure 2. To account for the larger size, we can either suppose that several of these cells have fused together or the cytoplasm of a single cell is thinned out by the method of cultivation.

The structure of the granulocytes is not very much changed. The larger forms with glistening granules and half-moon-shaped nucleus have diminished in number but smaller cells of the same type can be discovered now and then. In these forms sometimes fat droplets are visible. The eosinophil leucocytes are still abundant, but are surpassed in number by small ungranulated cells. These form now the bulk of the cells migrating into 
the surrounding plasma clot from the implanted tissue particle. They have either vesicular, less refractive or very shining and highly refractive nuclei.

In plate 2 we can follow in detail the further changes of the 'Riesenzellen.' The bone marrow (fig. 4) has been implanted 72 hours, from January 3 to January 6, 1916. Three round cells with big fat droplets can be seen, which seem to protrude out of the cell or cover its surface. The nuclei are therefore very seldom visible. When visible, they appear dark. A few granules are contained in the cytoplasm besides round or irregularly shaped masses, which seem to be remnants of other cells. On the third day after implantation these cells immediately attract the attention of the observer. They seem to have taken the place of the 'Riesenzellen;' this could be demonstrated by observation of the living cells. Some 'Riesenzellen' break apart, take on a round shape and completely extrude the fat droplets. These may be small or larger (fig. 5, second cell, left side) and show very fine pseudopodia. They are round cells which can survive an indefinite time in the plasma medium, the so-called 'cell culture type.'

Many 'Riesenzellen' however (fig. 5), the similarity of which to the round cells seen in figure 4 can be easily discovered, show all signs of degeneration. The cytoplasm has a 'curdled' appearance and is torn. The fat droplets have been thrown out into the plasma clot, and the granules have acquired a dark appearance. This regressive process takes place on the fourth or fifth day after implantation. These decaying cell masses are surrounded by small granulated and ungranulated cells and seem to be able to phagotise, because their cytoplasm shows in some places 'curdled granules.'

During the next days of incubation, no striking changes take place. The number of living cells diminishes and few types of cells are in healthy condition.

Fig. 6 shows cells which have been incubated in the same plasma medium 216 hours (from December 25 to January 3). They have small distended nuclei which do not seem to contain much chromatin, and the cytoplasm is filled with shining 
droplets. They belong to the so-called 'cell culture' type. Besides these cells we find others with oblong nuclei and elongated cytoplasmic bodies full of glistening fine granules. These move slowly and show fine pseudopodia formed by their delicately granulated cytoplasm.

To summarize: Fat containing bone-marrow of chicken when incubated for 9 days in a plasma medium, undergoes the following changes which can be observed in the living preparation: The signet-like fat cell disappears, it is transformed to 'Riesenzellen' and finally to the 'cell culture' type. This type includes round cells with coarsely granulated cytoplasm, big shining droplets and oblong; less refractive nuclei. The other prevailing cell-form is distinguished by its finely granulated cytoplasm, elongated or round cell body, and oblong nucleus.

These two cell types (not widely different in their morphological bearing) are always to be found among the cells which have migrated from the implanted bone-marrow particle into the plasma clot. Besides these cell forms,-capable as it seems of metabolism for long periods,--we see all forms of disintegrated cells. The cytoplasm and nucleus separate and the preparation is filled with débris. Fat droplets of different sizes which are freed from the cell fill the preparation. Nuclei of small granulocytes and lymphocytes without cytoplasm are often seen. Also shadows of blood corpuscles and granulocytes of all sizes are present.

It is certain that in non-renewed tissue culture retrogressive and progressive processes take place. It will be necessary to investigate the more intimate phenomena of these changes in stained preparations specially adapted to the study of each different cell type by different methods of cultivating and staining.

THE FATE OF THE MONONUCLEAR AND POEYMORPHONUCLEAR EOSINOPHIL LEUCOCYTES OF THE BONE MARROW IN TISSUE CULTURE

While describing the changes of the living bone-marrow cells after they had been $1,24,42,72,96$, and 216 hours in the plasma medium,-the present author could give little or no definite 
interpretation of the changes observed in the different types. Some exact knowledge could be acquired only by comparing and combining the phenomena observed in bone-marrow cells in preserved and stained preparations after they had been in the plasma medium for well defined periods.

In figure 7 , an exact microscopic field of a bone marrow preparation, after 36 hours incubation, is shown. The implanted tissue particle would be (if shown on the drawing) on the left side of the preparation. The cells shown have migrated to the zone next to the implanted bone-marrow tissue particle which was taken from a full-grown chicken and contained fat

Eosinophil leucocytes in various developmental stages are numerous. They are in rapid amoeboid movement, and by continued fragmentation diminish in size and multiply in number. Their plasma is slightly basophil. The nuclei are strongly chromophil and the nuclear leucocytic structure in most forms is indistinctly developed. By comparing the nuclear structure with that of eosinophil leucocytes which have been 24 hours in cultivation (fig. 9) we can better distinguish the typical leucocytic network of chromatin particles and threads. The plasma of these leucocytes and of those figured in figure 8, which have been only one hour in the plasma medium, is acidophil and the round granulations are very distinctly recognizable.

Besides the changes in the cytoplasm of the leucocytes from acidophily to basiphily, other phenomena are noticeable. After one hour and still more after 36 hours incubation, the leucocytes of all sizes are losing and expelling the granulations. The nuclei of these forms have either become pale and indistinct (fig. 7, right side, below) or condensed and strongly chromatic (figs. 12 to 14). They may fade out to mere shadows and disappear.

The farther the polymorphonuclear eosinophil leucocyte advances into the plasma clot, the more its cytoplasm spreads out in the tissue culture. The granulations in consequence no longer appear lying closely together, but seem widely scattered in the cytoplasm. The leucocytes finally lose their power of cytoplasmic division. This happens generally on the margin of the plasma clot where the culture medium is thinly spread. The horseshoe--or kidney-shaped nuclei separate, become 
pyknotic and form round, chromatic bodies (figs. 11 to 19). The, acidophil granules become more and more indistinct, the cytoplasm is again acidophil, and partly vacuolized. In this stage, long chains of these forms closely lying together cover the outer zones of the preparation, giving it a reddish halo. Later these cells without granules flatten out entirely, lose their nuclei or their chromatic particles, and undergo total destruction.

To summarize: most mononuclear and polymorphonuclear eosinoiphil leucocytes with either round, kidney-shaped, or lobulated nuclei, during the first hour of their emigration (fig. 8, and fig. 43) into the surrounding plasma, divide rapidly. They form smaller cells with fewer granules and a more basophil cytoplasm. Later by dividing and moving to the outskirts of the plasma clot, they finally form rays and layers of partly acidophil, vacuolized 'cells' without nuclei and granules. Another group of these eosinophil leucocytes, before diminishing in size in the zone near the implanted bone-marrow particle, had extruded its granules at a very early period. They fade out and leave their more basophil cell bodies in the plasma clot. The mononuclear or polymorphonuclear eosinophil leucocytes undergo a regressive development in tissue cultures.

These conclusions agree with the writer's own observations of the cells in living preparations. On the first and second day of incubation the eosinophil leucocytes are numerous and of normal size (fig. 2, left side, above). On the fourth and the fifth day the few forms, which have not undergone the flattening-out process and which have not changed their character, are small, with fine granules and an ellipsoid nucleus (fig. 5, left side, below). Foot ('13, pp. 49-51), in his account of the changes of the eosinophil leucocyte in the culture medium, reports that these cells finally take on the same form as that assumed later by the large mononuclear lymphocytes, and cannot be distinguished from them. With this conclusion the present writer cannot agree. In figure 8, the emigration of small leucocytes is shown. The lean, almost fat-less bone-marrow orginated from a young, not full-grown chicken. After an hour in an identical preparation the tissue was extracted and only the emigrated cells were allowed to develop. All cell types which 
are pictured in figures 11 to 26 are cells which have emigrated early from the bone-marrow particle, advanced to the border of the plasma medium, and changed in different ways.

Figures 11 to 19 show the regressive development of the polymorphonuclear leucocyte which is inserted in the plasma, either as a younger form, with spherical nucleus, or as an older form with kidney - or horseshoe-shaped, or lobulated nucleus always recognizable because of its acidophil granules. The long chains of these deformed cells in all transitions are easy to identify in preparations, where only a few cell types have been allowed to emigrate into the plasma. Here they never take on the character of the 'cell culture type' (Foot).

When bone marrow is taken from a young, poorly fed chicken and treated as above described, few 'mononucleäre basophile Zellen' emigrate in the first half hour, and the bulk are only eosinophil leucocytes (fig. 43). If these preparations are allowed to develop two or three days the rays of cells consist for the most part of these eosinophil leucocytes and few $\mathrm{X}$ cells or forms of the cell culture type are visible. If the process of extracting and again implanting the bone-marrow particle is repeated and the cells of the succeeding emigrations are controlled, few eosinophil leucocytes are observed in the second and third stage and after the third implantation approximately no eosinophil leucocytes are to be seen.

Therefore, no new formation of this cell type from a stem cell could be observed in the plasma clot, but only a process of emigration, multiplication, transformation and degeneration of those forms which were implanted with the bone marrow in the plasma clot.

THE FATE OF THE ERYTHROCYTES AND THE ERYTHROBLASTS IN THE BONE MARROW' IN TISSUE CULTURE ${ }^{2}$

The general rule for the behavior of cells in tissue culture: the more they are differentiated, or adapted to certain functions,

${ }^{2}$ Erdmann, Rh. 1917 Some observations concerning chicken bone marrow in living cultures, Proceedings of the Society for Experimental Biology and Medicine, vol. 14, pp. 109-112. 
the quicker they undergo destruction holds true in the case of erythrocytes. The red blood corpuscles appear often without a nucleus or without a shadow of a nucleus. The plasma seems perforated. This indicates that the haemoglobin has disappeared. Those cells in which we can trace only the shadow or a faint remainder of the nucleus are apt to deceive the observer. The remainder of the nucleus appears like a small parasite but is nothing more than the nucleus of the cell, as can be proved by numerous intermediate forms. These bodies resemble the Cabot's bodies which are described by Juspa ('14, p. 429) in certain diseases of men. Also the nuclei may become pyknotic in other forms and the plasma may disappear. Foot ('12, p. 461, and 1913, p. 46) notes these same two different ways of degeneration in erythrocytes. Their dead nuclei or their plasma is often incorporated into phagocytic cells (figs. 34 and 35) the origin and types of which will be discussed later.

The non-elongated round or irregularly shaped erythroblasts have a pale yellowish or colorless plasma (figs. 1 to 3). Well developed erythroblasts are distinguished when stained by their wheel-like, highly chromatic nucleus. Unstained cells show a whitish appearance of the nuclear membrane which seems crowded with the content of the nucleus and ready to break. Figures 3 and 7 represent erythrocytes and erythroblasts in various stages of their retrograde development. Their plasma-less nuclei cover the microscopic field and are often seen incorporated into cells of phagocytic character. Unripe, young erythroblasts are figured in figure 8 . They have larger nuclei in proportion to their basophil plasma than the erythrocytes and are scattered, through the tearing apart of the bone-marrow network, in large quantities into the surrounding plasma. They are recognizable in stained preparations by the smooth surface of their plasma and their chromatic nuclei and cannot be confused with "eine Art von basophilen mononucleären Zellen" which, according to Foot '12, form the $\mathrm{X}$ cells and the cell culture type.

But the difficulty begins when very young, i.e., small cells characterized in the first day of incubation by their situation near the bone-marrow network, are to be isolated and cultures 
from young living erythroblasts and from young basophil cells with vesicular nuclei are necessary, for deciding different questions. My experiments only proved, after isolating young cells near to the bone-marrow network that they underwent no transformation into erythroblasts but showed the phenomena fully described later on page 94-100 the transformation into cells of connective tissue cell type. It is naturally not excluded that erythroblasts-when they are already erythroblasts in a strict sense-divide in the tissue cultures, but I never could isolate this cell type with any certainty just at the point in being transformed from its 'stem cell' into erythroblasts. This phenomenon seems not to take place in tissue cultures.

THE FATE OF THE IMPLANTED MICROLYMPHOCYTES IN TISSUE CULTURES OF BONE MARROW

The microlymphocytes in chicken bone marrow are found in great quantities. Their small protoplasmic brim and condensed, highly chromatic nuclei allow us to distinguish them easily from the small basophile round cells with vesicular and achromatic nuclei, closely situated to the network of the bone marrow. The microlymphocytes seem to be present in the tissue cultures from the first day of the incubation of the bone marrow, without apparent changes, until the last day of cell life in the culture. But are those the same forms which were incubated or newly originated forms? The microlymphocytes implanted with the bone marrow particle must be capable of active movements, because they are no longer visible in the meshes of the bone marrow network after several days' incubation, but are always present in the plasma clot. In the preparations where only a few cells are allowed to emigrate and to stay several days in the plasma medium, the microlymphocytes are widely scattered. Their own cytoplasm expands in a star-like manner, often forming long cytoplasmatic rays. After a fortnight in the culture medium, they have the appearance of forms such as the cells pictured in figure 25 . One cell appears normal; the other has a torn cytoplasmatic body. Figure 27 shows the remaining nuclei which will soon undergo complete destruction. Foot '13, page 43 , believes that besides numerous microlymphocytes, 
which die, a large number 'steadily increase in size' and either form cells of the macrolymphocytic type or of the large mononuclear. lymphocytic type, "after the latter has undergone nuclear enlargement and dechromatization." Foot presents no drawings of these highly important forms, but considers it sufficient to record the measurements of microlymphocytes of different sizes, measuring from 3.5 to 9.6 in diameter. The nuclear structure of these transition forms is not described by him. The present author has never seen cells with typical microlymphocytic condensed nuclei in all sizes, only cells with vesicular achromatic nuclei in every possible size. In the later discussion these contradictory reports of Foot and of the present author must be borne in mind.

Some authors hold the theory that microlymphocytes originated from the large mononuclear lymphocytes by multiple simultaneous divisions. Only in very recently incubated tissue cultures, as recorded on page 79 a breaking of large lymphocytic forms into pieces was observed. But the isolated cultivating of these small cells afforded no definite results. Multinucleated forms with ragged or torn cytoplasmic structure and nuclei with highly condensed chromatin may be observed in the case illustrated, of which three have a condensed chromatic structure (fig. 8). The younger the implanted bone marrow is, the more numerous these forms appear to be. They have a slight resemblance in their plasma to very young connective tissue cells, as, e.g., Maximow ('10) pictures them in figure 43 , from a guinea pig, but they seem to have no connection with the formation of bone marrow lymphocytes.

To summarize: The microlymphocyte belongs to those cell types which undergo no progressive development in the tissue culture.

THE FATE OF THE IMPLANTED MYELOCYTES IN TISSUE CULTURES OF CHICKEN BONE MARROW

From the first to the sixth day after incubation large cell types can be observed in the tissue culture of bone marrow when the experiment is conducted with a full-grown, over a half year old ehicken. These cell types have, as described on page 79, 
before staining and preserving, a half-moon shaped, or elongated nucleus, and their plasma is either granulated, or the granules are invisible during cell life. The cells shown in figure 2 , two granulocytes and one ungranulated large cell, have only been one day in the culture. The first type appears to divide; we can observe smaller forms on the following days, with larger granules than the eosinophil leucocytes possess. The other represented cell type is a large lymphocyte. These forms may break in pieces during observation. After six days incubation we discover in stained preparations the changed form of the myelocytes (figs. 39 to 42 ). The reddish ripened nucleus of these forms has all the characteristics of a myelocytic nucleus. But in eosinazur stains such nuclei are generally supposed to have a more bluish color. This must be explained by the rising acidity of the culture medium in growing tissue cultures (Rous, '13, p. p. 183-86). The cells in figures 39 and 41 must be considered eosinophil myelocytes, those in figures 40 and 42 mononuclear lymphocytes. In earlier stages of their degeneration process these large forms often have very fine acidophil granules in their cytoplasma when observed on the second or third day of incubation; but they are never seen to divide. Their plasma loses its granulations, flattens out, and vacuolizes. The eosinophil myelocytes and lymphocytes have only a regressive development in the tissue culture medium.

THE FATE OF THE FAT CELLS OF THE BONE MARROW IN TISSUE CULTURE

But one observation of the behavior of fat cells in tissue culture is given by Foot, who writes ('12, p. 447,) that the cultivation of subcutaneous or subepicardial adipose tissue was without success, growth of considerable amount could not be observed. The present writer repeated Foot's experiments. Adipose tissue of the omentum of the chicken showed, after three days incubation, almost a complete disintegration; further, the formation of few cells of the 'cell culture type' and the survival of connective tissue cells could be observed. It may be conceived that some connective tissue cells may have originated 
from fat cells losing their fatty contents and assuming the character of the known type of connective tissue cells. Or the connective tissue cells, implanted together with the adipose tissue may have developed and multiplied. This is a separate question which has not been sufficiently studied in true adipose tissue.

The changes of the fat cells of bone marrow in tissue culture, though not considered by all authors to be real fat cells, have a great resemblance to phenomena seen in rapidly growing embryonic adipose tissue, as Foot remarks (p. 48, '12). But he himself, neither in 1912 nor in his later publication of 1913, states the ultimate fate of the implanted, so-called fat cells, which, together with the other cells of the bone marrow, are in the culture medium and are numerous in the white bone marrow of the adult chicken. The typical signet-ring cell may apparently remain unchanged for 24 hours in the plasma medium, as it is shown on a photograph (fig. 46, right side, above). But the observed facts do not agree in most cases with this view. After three hours incubation all fat cells show still their accustomed shape. The big fat globule surrounded by a brim of cytoplasm flattens out and the large globule of fat separates into small droplets. Or the fat cell divides into two parts, and even a process of budding may be observed (figs. 29 and 30). If the cell has not divided up, the fat globule diminishes in size and does not fill the whole cell. With a specific fat stain it can be shown that the cytoplasm. is filed with small fat droplets and strands (fig. 28). Later foamlike masses of cytoplasm, in the meshes of which the fat is easy to identify, protrude from the cell margin and separate themselves partially or totally from their 'mother cell.' Cells of this kind may. offer the appearance of cells figure in figure 2, left side, in unstained preparations. In a tissue culture of 24 hours inculation, preserved with Orth's fluid and stained with Giemsa stain, they appear as cells with highly chromatic nuclei, and perforated cytoplasm (figure 7 , right side and figures 33 and 34); also weblike masses, apparently without nuclei, are frequent (fig. 7) which are often surrounded by microlymphocytes and polymorphonuclear leucocytes. Text-figure A gives 
the most striking phases of the activation of a fat cell. The original fat cell, the fat cell which has extended fine pointed processes, and the final stage that comprehends cells containing vacuoles which may still have traces of fat in them. (Compare cells on figure 2 ; figure 7 , cell right side, above; and figures 45 and 46.$)$
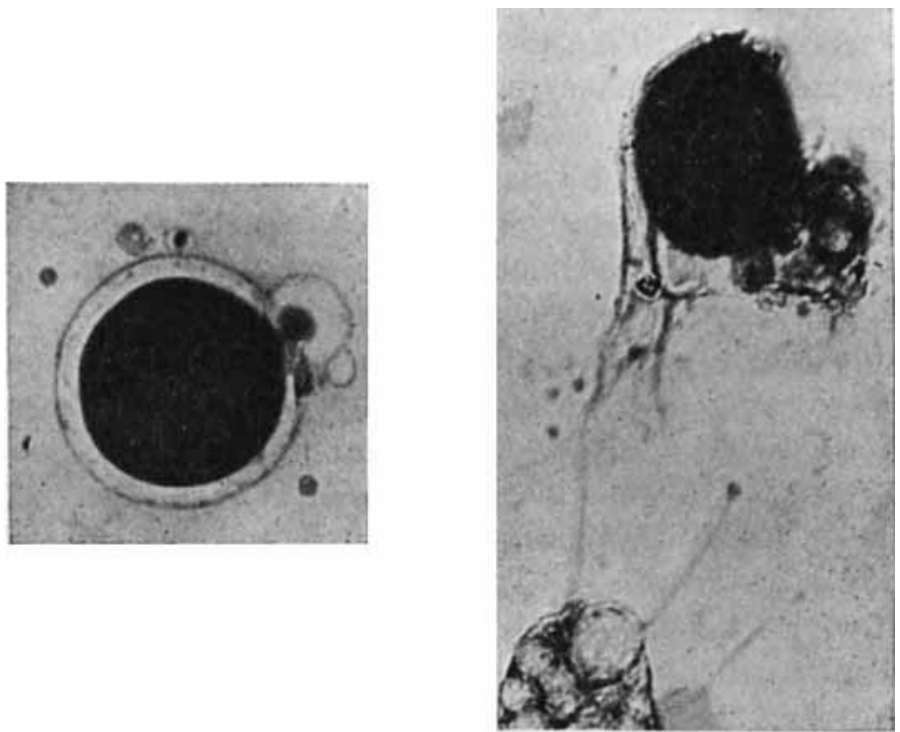

Text fig. A. Fat cells after 6 and 12 hours incubation.

It must be kept in mind that these changes occur during the first 24 hours or 48 hours of incubation. Figures 45 and 46 show that in a 30 hours culture the dissolving of the big fat globules and the dividing up of the fat cells has been in progress. The cells form chains, typical for the stage of the culture of 24 to 48 hours of fat containing bone marrow. These cell chains flatten out, fine processes are extruded which cover great areas and may fuse with other cells in web-like masses. Figures 45 and 46 give a good surview of this process and such a cell is also represented in figure 33 . We note its enormous size, its big vacuoles, its slender processes, its phagocytic capacity and its small nucleus. In short, we see a so-called 'Riesenzelle' of Foot 
which is already present after 24 hours of incubation. Now Foot ('12, p. 459, fig. 5) gives the photograph of a preparation of bone marrow after 5 days of incubation in a plasma medium. This is a descrepancy for which no explanation could be found.

It is of importance to state that all vacuoles do not contain fat in such a condition as to make it visible by the osmium process. The cell (fig. 32) shows still some fine traces of fat, but in many preparations which were treated with Scharlach or Sudan stain after adequate fixation, the vacuoles were devoid of fat. It is conceivable that fatty acids or other products of related character fill the vacuoles, but even after trying the most complicated stains (Ciaccio, Benda) to elucidate the nature of the contents in the vacuoles, no final decision could be reached.

From the third to the fifth day, the number of 'Riesenzellen' has diminished; we see smaller round or oblong cells with one or several vacuoles, with oblong faintly chromatic nuclei (fig. 34). They are the products of the breaking up of the 'Riesenzellen' and seem to be identical with Foot's cell culture type. They are capable of phagocytosis and move slowly toward the periphery of the plasma clot.

How can we interpret these extraordinary changes in the fat cells? The only similar observation was made by Maximow ('04, p. 108), describing the changes occurring in the cells of inflamed connective tissue of the rat. There he gives a good description of the involution of the fat. cells. The process shows the same phenomena in the involution of the fat cells in the connective tissue of the living animal after inflammation as are to be seen in tissue culture. The flattening out of the cytoplasm, the dividing up of the big fat globule into small droplets inside the cell (Maximow, plate 3, fig. 9; Erdmann, text-fig. A) and the transformation of the plasma in a honeycombed mass (Maximow, Plate 3, fig. 11; Erdmann, fig. 7, left side, above), are identical processes in both cases. Maximow believes ('04, p. 119) that some of these cells become fibroblasts. The present author ventures no opinion on the subject, though a striking similarity exists between the fibroblasts of Maximow (text-fig. B) and the cell in figure 7, right side above. 
We find after the second day in our cultures: (1) cells of the fibroblast type; (2) cells of the 'Riesenzellen' type; (3) cells of the cell culture type, after Foot. All three types can originate from the implanted fat cell.

Besides these progressive changes we must state that many implanted fat cells undergo destruction. This is shown by the observation of the living cells as described on pages 79 to 81 . Figure 4 , shows such a disintegrating mass of fat cells from an unstained preparation, and figure 7 , shows the mass in a stained preparation. Here two cells of the honeycombed type are recogniza-

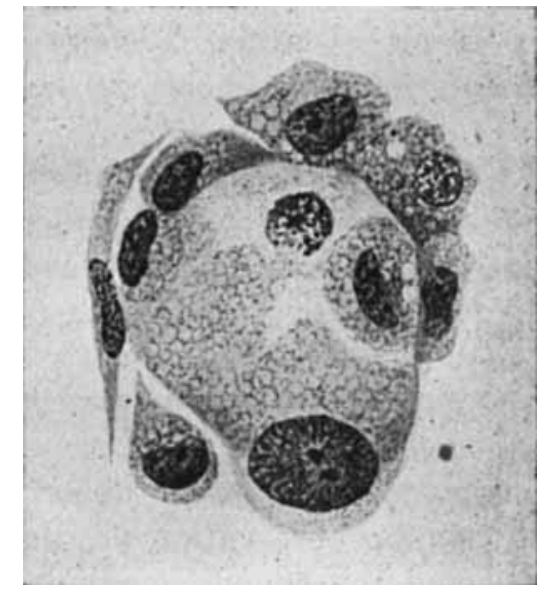

Text fig. B Maximow, 1914, figure 8, plate 3. Involution of a fat cell in an area of inflammation into a fibroblast.

ble (left side, above), one of which is intact, the other has expelled the contents of the plasma. Microlymphocytes are gathered around the disintegrating fat masses and the transformed fat cells. Maximow describes how his polyb asts, cells of the lymphocyte order, crowd around the fat cells and destroy them by phagocytosis (page 120). The same phenomenon occurs in the tissue culture; between the second and the fifth day the destruction and resorption of the dying fat cells is finished and the tissue culture gradually assumes a different aspect, as will be described later. 
But together with these retrograde processes, easily observed in the living culture, small parts of the irregularly-shaped, large, disintegrating fat cells isolate themselves. They become spherical in shape and begin to wander away from their 'mother cells.' They can be recognized by their small nuclei, their coarse glistening plasma. They are identical with small fat cells. This 'rejuvenation' of the fat cell was only observed when bone marrow tissue of younger well-fed animals was implanted. Bone marrow from very young chickens and tissue from old hens seldom rejuvenate the fat cells, when such are present. In tissue from older hens the disintegration of the fat cells often obscures the observation of the other cell types.

THE FATE OF THE MONONUCLEAR BASOPHIL CELLS OF THE BONE MARROW IN TISSUE CULTURES

When implanted in the plasma medium, the bone-marrow particle itself appears basophil after preservation with Orth's fluid and staining with Giemsa stain. For a long period, up to 14 days, it shows a strong basophilic character. We have shown how fat cells and their derivatives generally have a strongly basophil nucleus and often a basophil plasma. Erythrocytes, erythroblasts, and eosinophil leucocytes, which show a strong basophily of the nucleus, emigrate or are washed out of the tissue particle and either perish or undergo the changes described The eosinophil leucocytes, diminishing the size of their nuclei and acquiring an acidophil cytoplasm, later form, together with the erythrocytes, the reddish halo around the implanted particle.

After the first emigration or washing out of the cell types mentioned, the tissue particle consists almost solely of basophil cells, which are very young, small, unripe erythroblasts, small lymphocytes, connective tissue cells of the bone marrow network, and basophil cells of all sizes and forms, the character of which is not at first recognizable. The thickness of the tissue particle prevents the closest examination, but these cells have always ungranulated plasma. In figure 8 , a general survey of these basophil cells is given, as they appear after one hour's in- 
cubation in bone marrow of a young nearly fat-less chicken. Two types besides the erythroblasts with their more or less pinkish plasma and their wheel-like nuclei are distinguishablecells with crude irregular cell plasma, as if it has been torn They possess small, condensed, highly chromatic nuclei (fig. 8 left side, above), or their cytoplasm has well-rounded contours and a very big nearly chromatinless nucleus. This type and its changes will now be described.

In figures 11 to 27 , different emigrated cell types of a similar bone-marrow particle are represented. The particle itself was twice extracted during an incubation period of 24 hours. The emigrated cells of each extraction stayed 12 days in the plasma until they were preserved and stained and later analyzed, so no new rear guard of eosinophil leucocytes and those mononuclear basophil cells, the fate of which Foot tried to elucidate, need be considered. According to this experiment, which was repeated several times, besides the eosinophil leucocytes the changes of which (fig. 11 to 19 ) have been fully treated on page 85 , six different cell types are recognizable after the second extraction.

1. Cells which resemble fat cells (figs. 20 and 21).

2. Cells which, by their nuclear structure but not by their cell plasma, resemble true connective tissue cells (figs. 22 to 24).

3 . Cells which are true connective tissue cells, from the type of endothelial cells (fig. 27).

4. Cells which are true connective tissue cells not shown in figures 20 to 27 but in figure 9 , with star-like, fine protoplasmatic processes and elongated, often cone-like șhapes, and a more mesenchymelike character.

5. Cells which are microlymphocytes (fig. 25 and also fig. 27).

6. Cells which are lymphocytes (fig. 26).

Cell types 3 , and 6 are not often found in preparations made according to the prescribed method. The lymphocyte with its fine red granules (fig. 26) shows all signs of degeneration. It appears highly probable that in the plasma clot the normal ripening out of the large mononuclear lymphocyte began but could not be fully accomplished owing to the conditions of the culture medium. The endothelial cell and the elongated connective tissue cells 
(figs. 27, 9, and 38) have not changed their characters. They already appear on the first day after incubation, because they could be observed in bone marrow culture of 24 hours incubation. The elongated connective tissue cell is highly amoëboid, and shows in its plasma, on the first days of incubation, fine and bigger fat droplets, which are coarser when stained with specific fat stains. Later their plasma looks as if pulverized with small fat droplets, still later they lose their fat and appear highly vacuolized. They repeat on a smaller scale the changes of embryonic subcutaneous connective tissue that had been incubated 14 days in a plasma medium. Because these cells appear after the first day of incubation (the present author has observed them after but five hours' incubation) it appears highly improbable that they originated from the basophil spherical cells in question. They are cells of the bone marrow network or the vessels of the bone marrow, which have been torn apart by the cutting of the bone marrow. They can be also observed in tissue cultures of true adipose tissue and are distinguished by their rapid division rate.

In most cultures of connective tissue made by various authors these cells have been described. Lambert and Hanes ('11) mention the accumulation of fat and the vacuolization of the cytoplasm in cells of mesenchymal origin. They represent tumor cells in their publication of 1911, plate 66 , figures 4 and 5 , of this character. Lambert himself in 1912, on plate 72, figure 3 and plate 74 figures wandering cells from the chick spleen. Some of these forms are more related to the connective tissue cell type in question, some resemble more the cell type seen in bone marrow cultures when the fat cells have begun the disintegration. In 1914, plate 44, figure 6 , he gives a good proof of this.

In figure 9, Carrel and Burrows, ('11), represent also fat storing cells of this type. They are said to be originated from an adult chicken spleen, while the first author must have seen the elongated vacuolized type ('13, plate 17, figure 16), in cultivated connective tissue. Lewis, R. M., and Lewis, H. W., '11, show on their figure 20, left side, in a chicken liver culture, highly vacuolized cells of the same type. 
This comparison could be continued but the facts prove already that among connective tissue cells of the most varied parts of the chicken body these elongated, finely vacuolized, slender cells appear with a true connective tissue cell nucleus. They are all similar to the figures of Foot representing his X cells (cf. Foot ' 12 , plate 22 , figures $8,16,19$ ). The connective tissue cell represented by the present writer in figure 9 , is taken from a young chicken and is not of the same size as some of those cells which Foot shows. When cells, however, were taken from the bone marrow of a full-grown chicken, they were of the same dimensions as those given by Foot, '12, plate 22, figure 8 .

Also, in the development of embryonic bone marrow tissue of the chicken, Dantschakoff, '09, depicts mesenchyme cells (plate 44, figures 5 and 6 ) which have a close resemblance to the above mentioned cell type (fig. 9). They are identical types, except that the latter may contain fat, the first are fatless. In this group must also be included the elongated forms of Foot's Riesenzellen which have pointed pseudopods.

To summarize: Though fat containing and often vacuolized the elongated cells with connection tissue like nuclear structure which appear in Foot's figures among his 'Riesenzellen' are true connective tissue cells. There can be no doubt that the granular lymphocytes, the elongated cells of connective tissue character, and the endothelial cells did not originate de novo in the tissue culture.

In studying the cells close to the connective tissue network of the bone marrow the present writer could only distinguish one well defined cell type (figs. 36 and 37). Small round cells with strongly basophil cytoplasm and large, faintly staining nucleus with two nucleoli are abundant. They are neither microlymphocytes nor mononuclear lymphocytes nor erythroblasts. They differ from the microlymphocytes by their vesicular nuclei, from the mononuclear lymphocytes by their size and their cytoplasm, from the erythroblasts by their nearly chromatinless nuclei and also by their size. In living cells the nuclei of erythroblasts appear whitish, the nuclei of these cells dark. If these cells, which migrate from the tissue particle after the leucocytes are 
washed out by continued changing of the plasma, on the second incubation are allowed to develop we find after a fortnight two different types: figures 20 and 21 , and figures 22 to 24 . The cell represented in figure 21 differs from the basophil cells which had been implanted into the tissue culture (fig. 8, and figs. 36 and 37) only by its size and by the more chromatic contents of its nucleus. These forms are numerous; they later contain fat or vacuolize, forming chains, the cells of which are always to be distinguished by their nuclear structure from the eosinophil leucocyte. The nucleus has a close resemblance to that in fat cells; it is vesicular with round bulky, chromatic contents.

The next group (figs. 22 to 24 ) have a true connective tissue cell-like nuclear structure. The nuclei are elongated and fine threads of chromatin form a true connective tissue nucleus network. The cytoplasm is basophil in most cases, but in certain parts of the culture and in very old cultures it becomes acidophil. The basophily or acidophily of cells is no constant character in tissue cultures. Rous ('13, page 183) points out the changes in acidity of growing cells. The cells themselves become acid in the culture medium, after having been basophil. Later they may regain their basophil character. The cells in question are true phagocytes (fig. 23). They contain fat, blood corpuscles, dead nuclei, and other disintegrating particles. They are sometimes polynuclear; as the cell body does not divide they form also the so-called 'Riesenzellen' of Foot. They are more agile after the first days' of incubation. In older cultures they assume round, spherical and oblong shapes, and their enormous protoplasmatic body divides up. They then form the cell culture type (fig. 6) the nuclei of which are always vesicular and not very chromatic.

Therefore, in the group of Foot's 'Riesenzellen' do belong besides the products of the involution of the fat cells and the implanted elongated connective tissue celltype with its finely vacuolized plasma, these forms (figs. 22 to 24 ) in which the nearly fat-less bone marrow of a young chicken was used. This gave conclusive proof that the small mononuclear basophil cell 
(figs. 8, 35, 36 and 37) after leaving the bone marrow network, can form 'Riesenzellen' which by their nuclear structure resemble connective tissue cells. They later become the cells to which Foot gave the name "cells of the cell culture type." They are enlarged, fat-storing or vacuolized cells capable of phagocytosis.

The results here presented, i.e., the change of the small vesicular basophil cell into true phagocytes and later into 'Riesenzellen' or cells of the cell culture type-were attained by using the bonemarrow of a young, fat-less chicken and the washing out of the undesired cell types, as polymorphonuclear leucocytes. But even if we use the fatty bone-marrow of a full-grown chicken and control the daily changes, the same fact is demonstrated. The first day after incubation (fig. 7) we observe a large number of basophil mononuclear lymphocytes. Three are shown in one microscopic field. Their pale nuclei, often of a lighter blue than the plasma, the irregular shape of their plasmatic body in which sometimes a few fine acidophil granules are visible, and their large size, make them conspicuous. Examining preparations of the same series a day later, the lymphocytes are very scarce. On the fifth day of incubation, when the disintegrated fat has been disposed of by the phagocytic activity of these basophil cells, characterized by their close position to the network of the bone marrow, they are by far the most numerous types in our tissue cultures. In the following days they grow and divide rapidly forming 'Riesenzellen' which can store fat, become vacuolized, and end in rounding off and becoming cells of the cell culture type, their nuclei with a fine thread-work of chromatin becoming more like true connective tissue nuclei. They can even lose their basophily but may always be distinguished by their nuclear structure from the products of the regressive development of the eosinophil leucocyte in tissue cultures.

It might be possible to interpret Foot's text-figure 5, (page 459, '12) as representing a tissue culture preparation just in such a stage; because the time for formation of these features is the same. But then it is not explained why Foot does not describe the formation of the 'giant cells' and cells of 'cell culture' type after 24 hours' incubation. 
In the above mentioned preparations the bulk of all cells, with their fat storing and phagocytic capacities, their vacuolized cytoplasm have now left the implanted bone marrow particle. They advance with their fine, pointed, plasmatic pseudopodia to the outskirts of the plasma clot. Their faintly chromatic nucleus has only two nucleoli. This character is evident in the youngest cells of that kind which are close to the network of the bone marrow (figs. 36 and 37) and is also found in 'Wanderzellen' after Dantschakoff (cf. Dantschakoff, '09, page 133), plate 7, figures 2 to 5 . These 'Wanderzellen' which originate from a mesenchyme or endothelial cell can, according to Dantschakoff, either be histiotypic or lymphocytic. They form in the embryonal development specific elements of the connective tissue or the hematopoëtic apparatus, according to the conception of the monophyletic school. In older cultures nearly all basophil cells have nuclei of true connective tissue cell character, e.i., the chromatic granules of the nucleus are connected with fine threads. They are identical with those nuclei figured in figures 22 to 24 . Not so frequent are types of nuclei figured in figures 20 and 21.

The 'Wanderzellen' in the tissue culture lose, in the later days of their existence, especially in unrenewed tissue cultures, their fine cytoplasmatic processes but are--by the structure of their nuclei and their cytoplasm-connective tissue cells of a more mesenchymelike character. They are transformed to cells of the cell culture type.

That these cells are descendents of the implanted cells, which were lying close to the bone marrow, is further proved by the following experiment. After all loose cells in the meshes of the bone marrow are washed out by repeated changing of the plasma medium, cells of the type in figures 20 to 24 , can be formed. After three changes of the culture medium, with a period of two days between, the cells close to the network formed vacuolized cells which could be interpreted in no other way except as 'Wanderzellen.' 'Their nuclei had become nearly chromatinless, and their plasma acidophil; they sometimes assumed the character of fat cells, but were generally of the 'Wanderzellen' type. 
No large mononuclear lymphocytes could be seen. It is, therefore, also evident that a new formation of this cell type, the mononuclear large lymphocyte of the bone marrow, does not occur in the tissue culture. The smaller and larger basophil cells with a vesicular nucleus near the bone marrow network, and the cells which later leave the network are 'Wanderzellen,' a type closely related to the mesenchymal cell. They can be kept alive for longer periods in renewed culture-medium.

The empty network of the bone marrow, consisting of slender connective tissue cells, has lost its power of sending new cells into the surounding plasma clot. The network cells remain living for long periods in renewed medium changing only their cytoplasma in the same manner as other connective tissue cells do in plasma culture. It becomes perforated with sieve-like vacuoles which may store fat.

\section{SUMMARY}

The growth of chicken bone marrow in chicken plasma may be divided into two distinct periods. The first period has a more regressive character. As process of this first period may be enumerated:- the degeneration of the erythrocytes and the nearly full-grown erythoblasts, the ripening of the granulocytes implanted with the bone marrow into the tissue culture; and the decay of the latter.

The eosinophil mononuclear or polymorphonuclear leucocytes after rapid multiplication lose their granules, are flattened out, and form cell chains of acidophil character which undergo slow destruction.

The myelocytes moving at first amoëboid-like in the plasma clot, and behaving like phagocytes, seldom divide, but ripen out until they assume a large size. Then their plasma vacuolizes and disappears, leaving only the nuclei.

The microlymphocytes show no signs of multiplying. They leave the meshes of the bone marrow particle; later lose their cytoplasm; and finally leave their condensed nuclei in the culture. 
The large mononuclear lymphocytes of the type occurring in the flowing blood, present in great numbers after the first day of incubation, form now and then fine granules, but undergo no further development into myelocytes. They lose their nuclear chromatin, and their plasma becomes honeycombed and finely vacuolized, and they finally leave as the only trace of their existence faint shadows in the plasma clot.

The so-called fat cells of the bone marrow flatten out; the big fat globules divide into smaller droplets; their plasma either vacuolizes and forms long needle-like projections, or fibroblastlike cells with a central nucleus and honeycombed plasma. The first cell type is phagocytic. These cells represent 'Riesenzellen' in the first period of the tissue culture growth. Not all cells of this type are transformed into fibroblasts or 'Riesenzellen.' Some fat cells disintegrate filling the culture medium with degenerating fat particles. Now and then the nucleus, with a small amount of cytoplasm separates from the dying 'fat cell' and a young 'rejuvenated' cell of fat cell character appears. The so-called fat cells combine the first regressive period of bone marrow growth with the second of more progressive character. Some undergo destruction, some survive, later assuming Foot's cell culture type.

From the first day of incubation, connective tissue cells of elongated shape with very fine pointed projections migrate into the plasma clot. They store fine droplets of fat and partially vacuolize. They are also found in the second period of growth in the tissue culture.

The second period begins with the loosening up of the cells around the network of the bone marrow; the smaller, or larger basophil cells, with vesicular nucleus migrate into the surrounding plasma and the network sends new cells into the plasma clot till it is utterly devoid of cell forms. These cells represent an intermediate type between the 'histiotype Wanderzellen' (Dantschakoff, '09) and the embryonic mesenchyme cell. They do not resemble in all details the large nononuclear lymphocyte of the blood. They move into the surrounding plama, send out penetrating needle- and bristle-like projections; divide into phago- 
cytes; store fat; lose their projections and partially vacuolize, assuming the form of the "cell culture type."

The network of the bone marrow, having lost its cells, and no longer able to send out emigrating cells, consists of slender connective tissue cells. These show a remarkable paucity of chromatin, are strongly acidophil, and possess sieve-like vacuoles of the finest type.

The 'Riesenzellen' of Foot comprehend several cell types:

1. Transformed fat cells and elongated, vacuolized connective tissue cells.

2. Newly emigrated basophil cells of the bone marrow network, which are related to the "histiotype Wanderzelle" of Dantschakoff.

3. Some few myelocytes and flattened out eosinophil monoor poly-morphonuclear leucocytes.

These two phenomena, the dying of the cell forms which are not adapted to the continued growth in tissue culture, and the adapting of a new character by those cells which are capable of living longer periods in the plasma medium, often overlaps. They appear more sharply separated in cultures of almost fatless bone marrow, where few 'Riesenzellen' appear in the first days of incubation. From the third to the fifth day, when the loosening of the bone marrow network and its content has begun, they become numerous. The duration of these periods may be stated as follows: The first period lasts from the first to the third day; the second period from the third day to the death of the culture. The surviving cells of the cell culture type (Foot) are modified fat cells and newly formed wandering cells of the mesenchymelike type. After fourteen days' cultivation, they are, except the elongated connective tissue cells the only living cells. They belong to the connective tissue cell type and may, when the medium is renewed, grow indefinitely.

\section{DISCUSSION AND CONCLUSIONS}

As one of the first results of our analytic study, let us discuss the fact that the so-called X or 'Riesenzellen' of Foot represent several different cell types. The myelocytes and larger eosinophil leucocytes acquire, as shown, good dimensions in the tissue 
culture of bone marrow. The myelocytes, capable of amoëboid moving, form few 'Riesenzellen.' They can easily be omitted in the following discussion, as they are always distinguished by their characteristic nuclei and the blunt form of their projections, when stained and preserved. They are just as unmistakable when living. The large.mononuclear or polymorphonuclear eosinophil leucocytes only need be considered, as X or 'Riesenzellen' when they have flattened out and formed rays of cells. Then they are surrounded by the projections of the transformed fat cells or cell types of the 'histiotype Wanderzellen' order. Both cell types are true phagocytes, thus forming, chiefly in the first days after incubation, cell masses of $\mathrm{X}$ or 'Riesenzellen' of combined characters. The whole combination may even seem, judged only by its acidophil staining, to be from a different origin. But the daily observations reveal the facts of their development. It is questionable if any necessity exists for giving new names, as Foot did in 1912 and 1913, for the X cells 'Riesenzellen' and later forms. They are either transformed fat cells, or mesenchymelike wandering cells which have left their customary place and which assume in later life in tissue culture the characters of connective tissue.

The name 'Riesenzellen' or true giant cells has already been used for cells of the type represented in figure 10. This multinuclear cell was seen in a tissue culture of bone marrow from a two-months old chicken, and resembles in every particular the true giant cells figured and described by many authors.

To call the questioned basophil cells ' $\mathrm{X}$ cells' when their origin is known would be a contradiction. They are either 'fat cells' or mesenchymelike cells, and both types are transformed from their original type by our cultivation method. The present author would propose calling the latter simply wandering mesenchymelike cells, and the fat cells, transformed fat cells. Their close relationship to the mesenchymal cell type is again proved by their physiological behavior in tissue culture, so closely identical with that of the wandering mesenchymal type. It even became evident that some 'fat cells' may assume the character of fibroblasts when they are not transformed into 
highly vacuolized or fat-storing cells of mesenchymal character with projections at first needle-like and later of a rounded or elongated shape. This twofold manner of development of the bone marrow fat cells is important, as it might probably be the result of a non-uniform origin.

In judging the transformations of cell types of mesenchymal origin in tissue culture, we already have established certain facts as a basis of comparison. The mesenchymal cells always grow more rapidly than any other known tissue; they have the ability to store fat; they can vacuolize and can emigrate out of the tissue clot. They can endure this highly artificial method of breeding indefinitely. The bone marrow particle, with its loose meshes, exhibits many 'Wundflächen' which are incited into new growth by the stimulus given by the cutting of the tissue. By repeatedly renewing the culture medium and transplantin the tissue particle, we stimulate the growth again and again, until we have exhausted the power of the network to send newly formed mesenchymelike cells into the plasma, and only a fine thread-like network with a few oblong, small nuclei remains. The pliability of the mesenchymal cell and its ability to undergo transformations is known in embryonic life and is here demonstrated in tissue culture life.

Two subjects of importance have not been touched. Can these wandering mesenchymal cells form fibrils, and have they any relation to the formation of the different elements of the bone marrow? Throughout the whole description of the cell transformations in tissue culture, the writer has avoided Foot's conclusion of 1912, namely, since his X cells form fibrils, they must be of the mesenchymal type. The tissue particle of bone marrow has a fibril-forming connective tissue of its own. When, now and then, fibril-forming cells have been seen (as has been the experience of the writer), they may either originate from cells already implanted in the tissue culture, with the bonemarrow particle, or the imbedded fibrils (Foot'12, plate 22, fig. 15) may represent fibrils or fibers formed by the fibrin-containing plasma of the culture medium (Baitsell '14, '15). Foot maintains that his $\mathrm{X}$ cells form fibrils but he does not prove it. 
Proof could only be obtained by cultivating isolated cells of a certain known type in a medium which does not contain fibrin as the plasma does. This has never been done and still remains a subject for future investigation.

The author agrees with Foot's view of 1912, that X cells, or the conspicuous cells in tissue cultures of bone marrow, are of mesenchymal type, not because they contain fibrils, but because their origin could be traced and their cytological changes could be recorded. Foot's statement of 1913, must be refuted: that the transformation passed through the stages of small microlymphocyte, macrolymphocytes, large mononuclear forms, myelocytes, polymorphonuclear eosinophil leucocytes, $\mathrm{X}$ cells, cell culture type, omitting one or the other forms of this stage, so that directly a lymphocytic origin is considered. It was never observed that true microlymphocytes were transformed into macrolymphocytes in the tissue culture. The basophil cell with vesicular nucleus, pale cytoplasm of various sizes in the network of bone marrow, assumed the cell culture type, after wandering into the cytoplasm, forming point-like projections, displaying the capability of phagocytosis, storing fat, and being vacuolized. There was no stage observed in this transformation which resembled the large mononuclear lymphocyte or the "lymphocytoid Wanderzelle' of Dantschakoff, though this type could be easily observed in chicken bone marrow when the bird had cyanolophia. The close resemblance with Dantschakoff's 'histiotype Wanderzelle'-cells which form ('09, page 177), after some changes, the 'ruhenden' wandering cells of the connective tissue - could, only be discovered when the basophil forms left the net-work and began to emigrate.

It appears highly plausible that in tissue culture the indifferent mesenchymelike cell in the bone marrow network does not show its supposed duality, either to form the known elements of the connective tissue or according to the views of the monophyletic school, the different elements of the hemato- and granulopoësis. In a medium, where circulation has ceased, where no oxygen renovation takes place, the potency to form the lymphocytic elements of bone marrow may not be strong enough to over- 
come the potency to form fat cells, fibroblast and 'histiotype' wandering cells. Therefore the present series of experiments does not prove anything concerning the views of the mono- or duophyletic schools, of the formation of blood and lymph in the bone marrow. Here renewed experiments should be made, the different cell types after emigration should be isolated and submitted to conditions reproducing either the condition of the blood or of the lymph. Only with still more refined methods would it seem possible to elucidate, outside the body, the complicated process of blood and lymph formation.

But this series of experiments proves that the latent qualities of the basophil mononuclear cells in the meshes of the bone marrow can arise de novo in the adult animal, because their wandering phagocytic, fat-storing character has been made evident. This fact ought to be considered in dealing with the appearance of these, and related cell types in the blood and lymph during diseases.

\section{BIBLIOGRAPHY}

Battseli, G. A. 1915 The origin and structure of fibrous tissue which appears in living cultures of adult frog tissues. Jour. of Exper. Medicine, vol. 21 , p. $455-479$.

1916 The origin and structure of fibrous tissue formed in wound healing. Jour. of Exper. Medicine, vol. 23, p. 739-756.

BeLl, E. T. 1909 On the histogeneses of the adipose tissue of the ox. Am. Jour. Anat., vol. 9, p. 412-438.

Burnows, M. T. 1910 The cultivation of tissues of the chick embryo outside the body. Jour. of the Amer. Med. Assoc., vol. 55, p. 2057.

1911 The growth of tissues of the chick embryo outside the animal body, with special reference to the nervous system. Jour. Exp. Zoöl., vol, 10, p. 63-83.

Carrel, A. 1913 Contributions to the study of the mechanism of the growth of connective.tissue. Jour. of Exp. Med., vol. 18, p. 287-299.

Carres, A. and Burrows, M. T. 1913 Cultivation of tissues in vitro and its technique. Jour. of Exper. Med., vol. 13, p. 387-397.

DANTSCHAKOFF, W. 1909 Untersuchungen über die Entwicklung von Blut und Bindegewebe bei Vögeln. Das lockere Bindegewebe des Hühnchens im fötalen Leben. Arch. f. mik. Anat, Bd. 73, p. 117-182.

1909 Utber die Entwickelung des Knochenmarks bei den Vögeln und dessen Veränderungen bei Blutentziehungen und Ernährungsstörungen. Arch. f. mikr. Anat., Bd. 74, p. 855-929. 
Emmer, V. E. 1914 Concerning certain cytological characteristics of the erythroblasts in the pig embryo and the origin of non nucleated erythrocytes by a process of protoplasmic condition. Am. Jour. Anat., vol. 16, p. 127 .

Foot, N. C. 1912 Über das Wachstum von Knochenmark in vitro. Experimenteller Beitrag zur Entstehung des Fettgewebes. Beitr. z. path. Anat. z. allg. Pathologie Bd. 53, p. 446-477.

1913 The Growth of chicken bone marrow in vitro and its bearing on hematogenesis in adult life, Jour. of Exper. Med., vol. 17, pp. 43-60.

HaRRISON, R. G. 1907 Observation on the living developing nerve fibre. Proc. Soc. Exp. Biol. and Med., vol. 4, p. 140-46.

1910 The outgrowth of the nerve fiber as a mode of protoplasmic movement. Jour. Exp. Zoöl., vol. 9, p. 787-848.

JusPA, V. 1913-1914 Uber den Entstehungsmechanismus der Cabotschen Körper und ihre diagnostische Bedeutung bei den experimentellen Anämien oder den schweren Anämien des Menschen. Folia Haematologica, Bd. 17, p. $429-441$.

LAmbert, R. A. 1912 The production of foreign body giant cells in vitro. Jour. of Exper. Med., vol. 15, p. 510-516.

1914 The effect of dilution of plasma medium on the growth and fat accumulation of cells in tissue cultures. Jour. of Exper. Med., vol. 19 , p. $398-405$.

LAMbert, R. A. AND HaNes, F. M. 1911 Growth of sarcoma and carcinoma cultivated in vitro. Jour. of Exper. Med., vol. 13, p. 495-504.

Lewis Reed, M. AND Lewis, H. W. 1911 Cultivation of chick embryo tissues. Anat. Rec., vol. 5, p. 277-288.

Maximow, A. 1904 Ưber entzündliche Bindegewebsneubildung bei der weissen Ratte und die dabei auftretenden Veränderungen der Mastzellen und der Fettzellen. Beitr. zur path. Anat. und zur. allg. Pathologie. Bd. 35, p. 93-127.

1909 Untersuchungen über Blut und Bindegewebe. Die frühesten Entwickelungsstadien in Blut und Bindegewebszellen beim Säugetier embryo, bis zum Anfang der Blutbildung in dem Leben. Arch. f. mikr. Anat. Bd. 73, p. 380-444.

1910-1911 Untersuchungen über Blut und Bindegewebe. III. Die embryonale Histiogenese des Knochenmarkes der Säugetiere. Arch. f. mikr. Anat., Bd. 76, p. 1-114.

Oppex, A. 1912 Causal morphologische Zellenstudien. V. Mitteilung. Die active Epithelbewegung ein Factor beim Gestaltungs und Erhaltungs geschehen. Arch. f. Entw., Bd. 35 p. 371-456.

1912 Über die Kultur von Säugetiergeweben ausserhalb des Organismus. Anat. Anz., Bd. p. 464-468.

1912 Kausal-morphologische Zellenstudien. IV. Mitteilung. Die Explantation von Säugetiergeweben ein der Regulation von seiten des Organismus nicht unterworfenes Gestaltungsgeschehen. Arch. f. Entw., Bd. 34, S. 132-167.

Rous, P. 1913 Growth of tissue in acid media. Jour. of Exper. Med., vol. 18 , p. $183-186$. 
Walton, A. J. 1911 Variation in the growth of adult mammalian tissue in autogenous and homogenous plasma. Proc. R. S. L., B., vol. 87, p. $452-61$.

1914 The effect of various tissue extracts upon the growth of adult mammalia cells in vitro. Journ. of Exper. Med., vol. 20. p. 554-573.

\section{EXPLANATION OF PLATES}

The drawings were made from total preparations, with Abbe camera lucida, Zeiss homogeneous immersion $2 \mathrm{~mm}$. and compensating ocular 12, with drawing board level with stage of microscope. Magnification about 1500 diameters.

\section{PLATE 1}

EXPLANATION OF FIGURES

The bone marrow used for the preparations shown in figures 1 to 6 was taken from a well fed, full grown chicken containing a large amount of fat. It was incubated at a temperature of $38^{\circ} \mathrm{C}$. in the chicken plasma medium.

1 The first cells emigrating from the particle into the plasma. Bone marrow one hour in plasma, January 3,1916, 10 a.m. to 11 a.m. Two mononuclear eosinophil leucocytes, one lymphocyte, and one normoblast are visible.

2 Cells which have left the implanted bone marrow particle after twentyfour hours and emigrated into the plasma. January 3 to January 4, 1916. Mononuclear and polynuclear eosinophil leucocytes with rod-shaped granules and large granulocytes with rounded, highly refractile granules are visible. Two fat cells at the right and left side of the preparation have divided up their big fat globule into small fat droplets (compare plate 6). In the middle a large nongranular Iymphocyte is to be seen.

3 Cells which have left the implanted bone marrow particle and have advanced to the border of the plasma clot after forty-eight hours' incubation. January 3 to January 6, 1916. One large 'Riesenzelle' and a small granulocyte with highly refractile granules are visible together with one small lymphocyte with vesicular nucleus. Red blood corpuscles with or without nuclei are present. One red blood corpuscle extrudes its nucleus.

6 Cells which have stayed two hundred and sixteen hours in the plasma medium December 25, 1915 to January 3, 1916. Cell culture types. 

RHODA ERDMANN
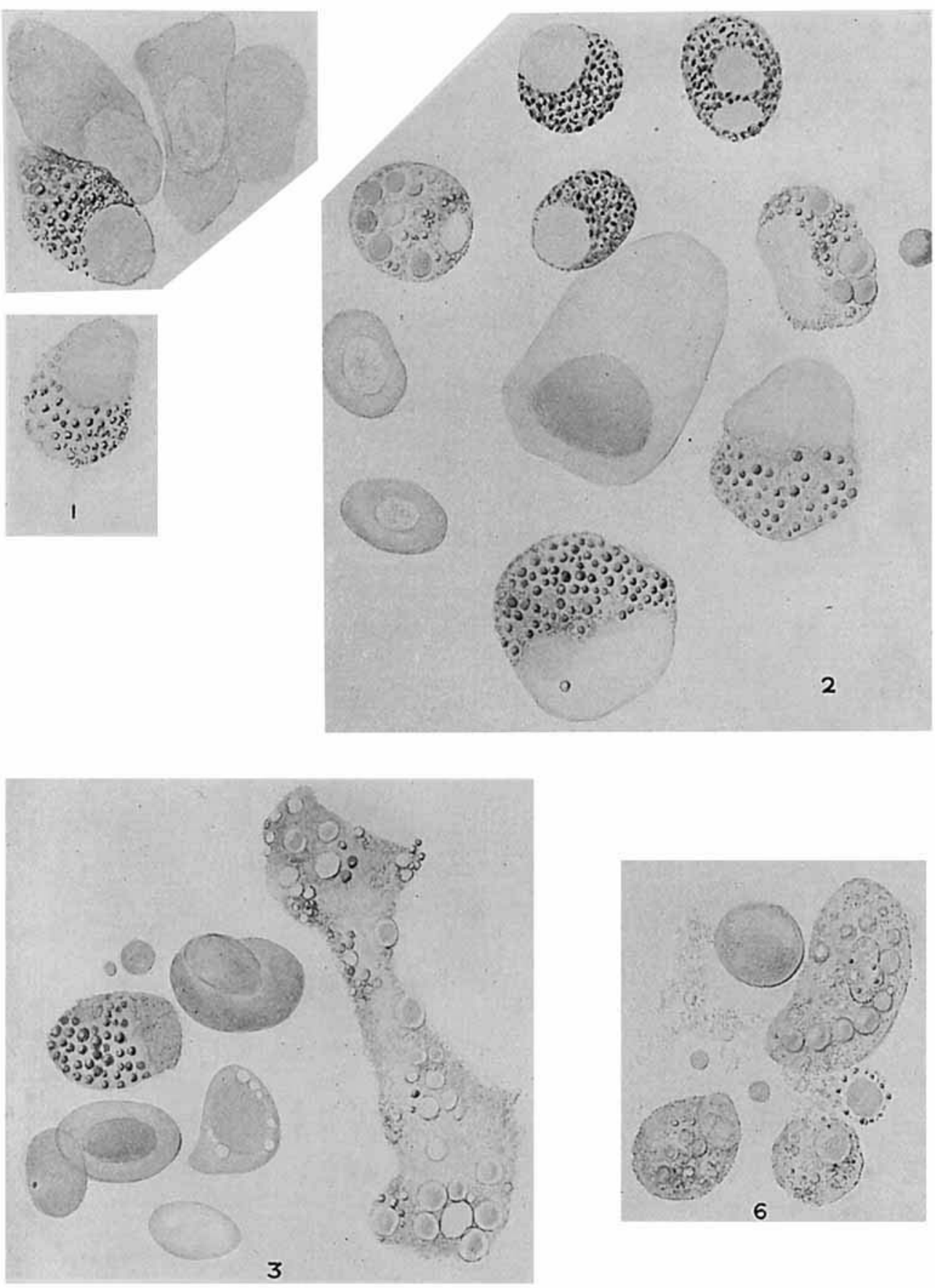
PLATE 2

\section{EXPLANATION OF FIGURES}

4 Cells near the implanted tissue particle after seventy-two hours' incubation. January 3 to January 6, 1916. Extrusion of fat droplets and breaking up of the 'Riesenzellen.'

5 Cells on the outskirts of the surrounding plasma after ninety-six hours' incubation. Disintegration of fat cells. Note the very small leucocyte. 

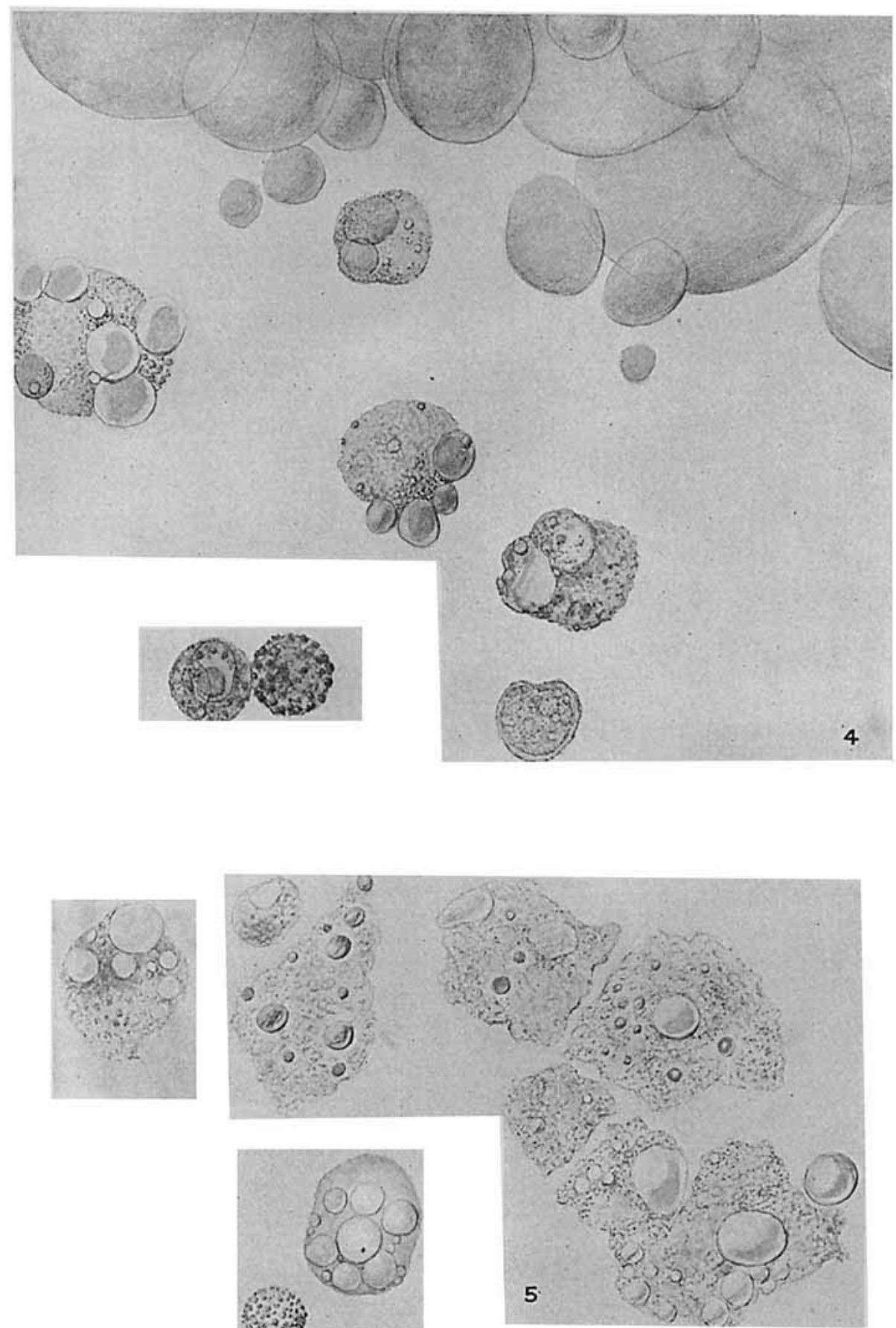


\section{PLATE 3}

\section{EXPLANATION OF FIGURES}

7 Total preparation: Bone marrow of a full-grown, well-fed chicken after thirty hours' incubation at $38^{\circ} \mathrm{C}$. in the plasma medium. January 3 to January 4, 1916. Orth's fluid, Giemsa stain. (Compare for explanation pages 89 and 98-100.) Actual field represented. 

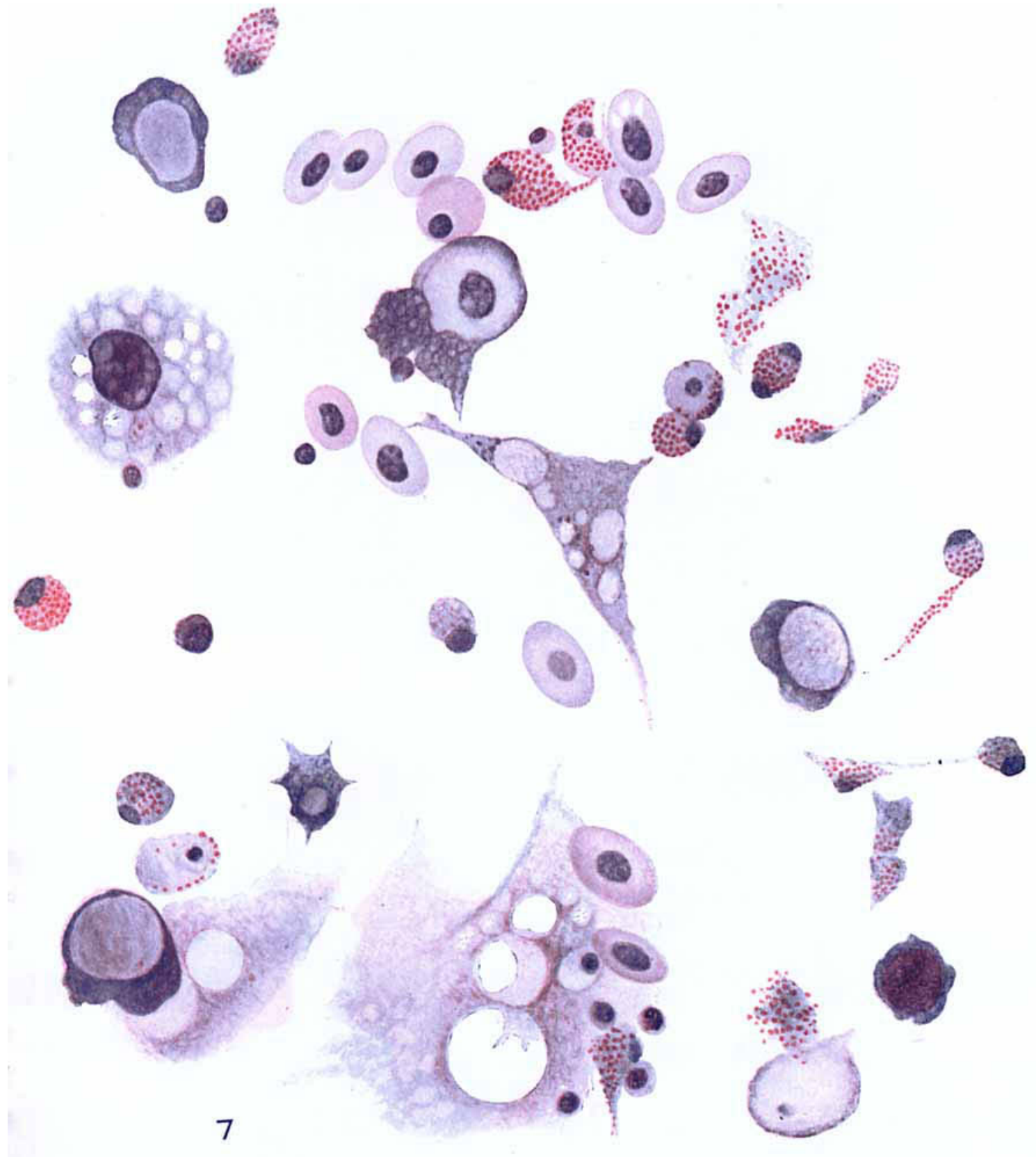

THF AMFHICAN JOTRNAL OF ANATOMY, VOL. 22 , NO. 1 


\section{PLATE 4}

EXPLANATION OF FIGURES

8 Total preparation: Bone marrow of a chicken not yet full grown, with a small amount of fat, after nincty minutes' incubation at $38^{\circ} \mathrm{C}$. in the plasma medium. June 7, 1916. Orth's fluid, Giemsa stain. Small eosinophil leucocytes and many basophil cells with vesicular nuclei are present.

9 Total preparation: Bone marrow of a full grown, well fed chicken, after twenty-four hours' incubation at $38^{\circ} \mathrm{C}$. in the plasma medium. December 14 to December 15. Orth's fluid, hematoxylin, eosin stain. The slender vacuolized cell with its nucleus of connective tissue cell structure is already visible after this short incubation period. 
CHICKEN BONE MARROW IN PLASMA MEDIUM

PIAATE 4 BHODA FRDMANN
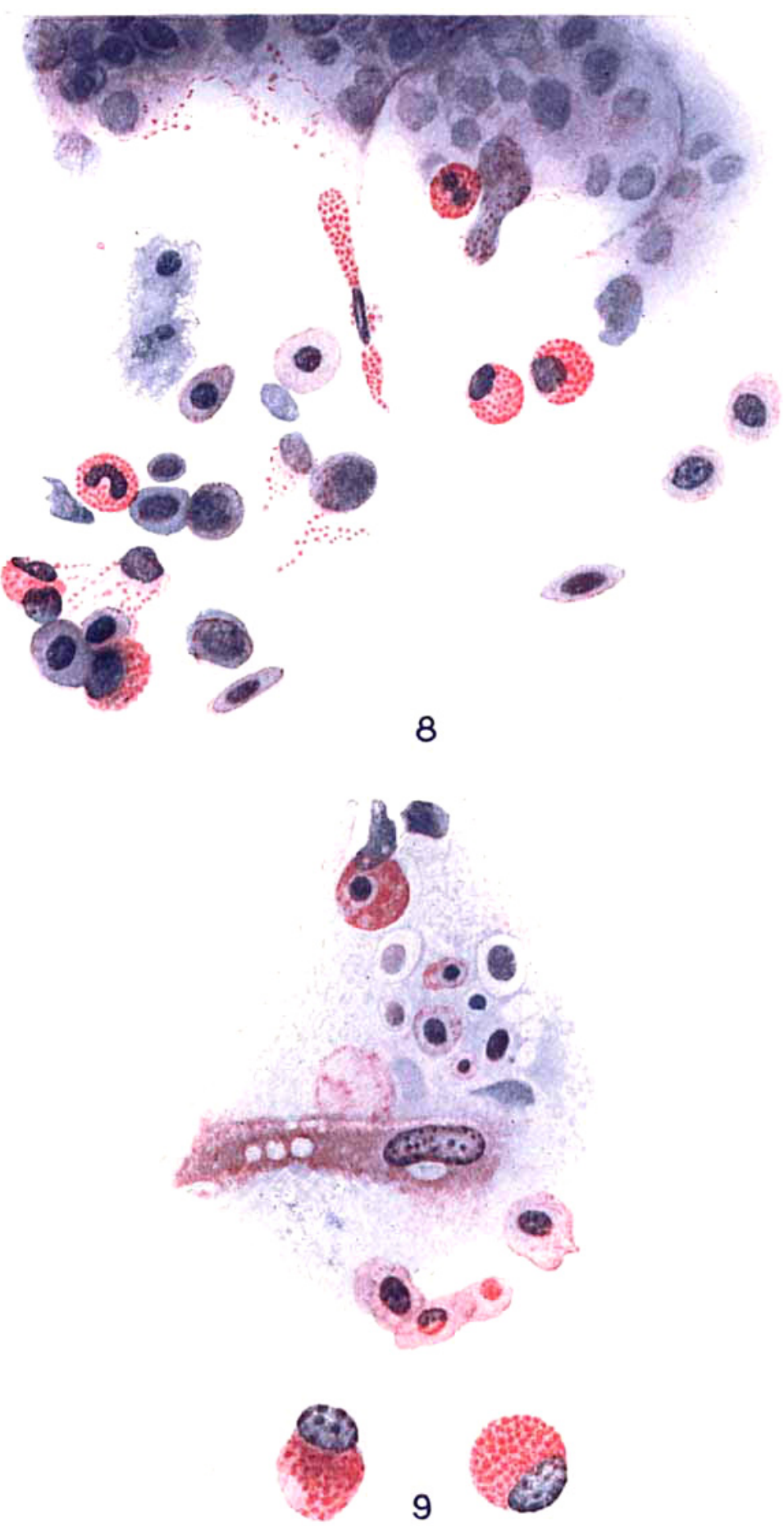


\section{PLATE 5}

\section{EXPLANATION OF FIGURES}

10 Giant cell from the bone marrow of a young, but full grown, well fed chicken, after one day's incubation; to represent the type which is generally named giant cell and is not identical with Foot's 'Riesenzelle.'

11 to 19 White bone marrow of a young, nearly fatless chicken in tissue culture at $38^{\circ} \mathrm{C}$. After one hour's incubation the tissue particle was extracted and the emigrated cells were allowed to develop further. February 11 to February 25,1916 . A detailed description of the changes of the eosinophil leucoeytes is given on page $8 \geq-84$.

20 to 27 The same bone marrow particle after having been freed from its eosinophil leucocytes by the above described process was implanted for one day again in a plasma medium and extracted again. The emigrated cells were allowed to develop from February 12 to February 25, 1916. Figures 20 and 21 represent a cell type more related to fat cells, figures 22 to 24 a type more related to connective tissue cells, figures 25 to 27 show known cell types which have not changed their character in the tissue culture. Note figure 24: a so-called form of the cell eulture type. All cells on plate 5 are conserved in Orth's fluid and stained with Gicmsa stain. 
RHODA ERDMANH
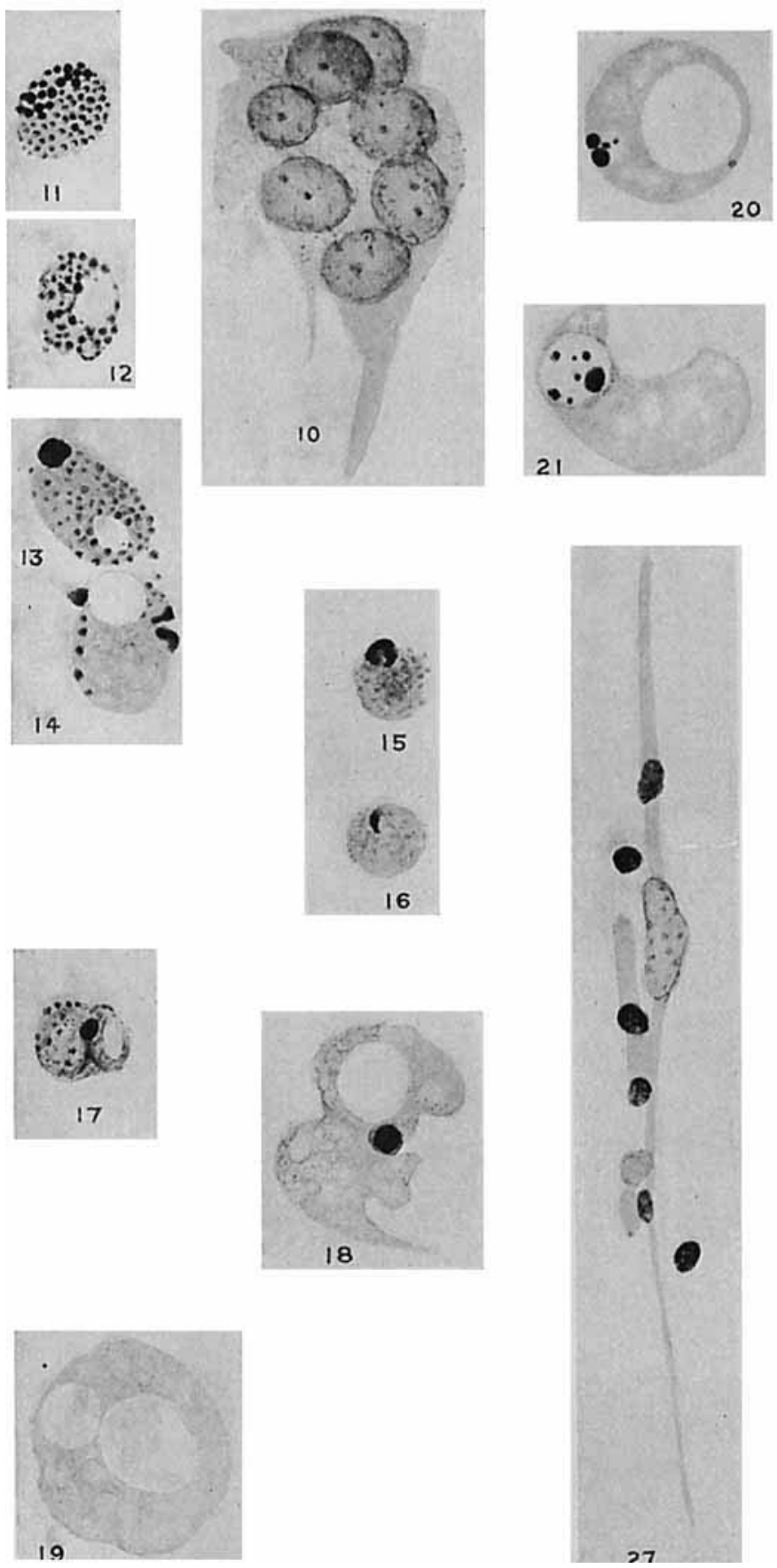

PLATE 5
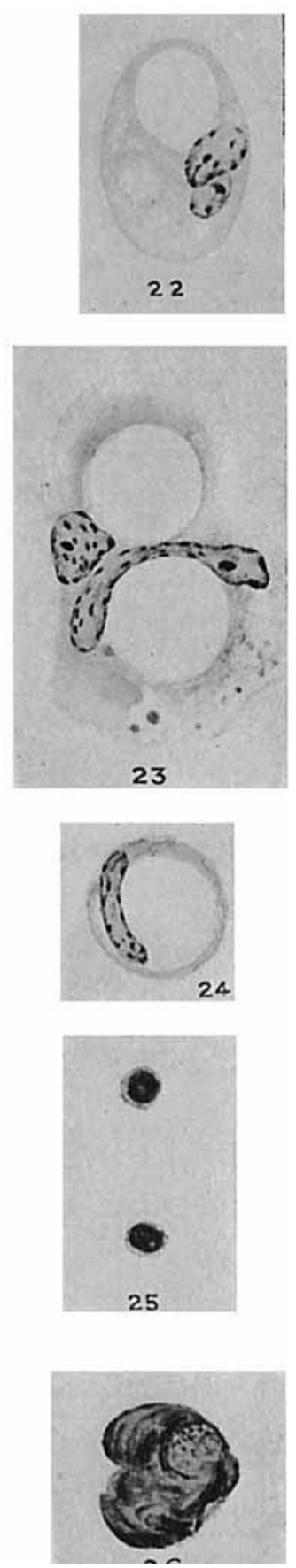


\section{PLATE 6}

\section{EXPLANATION OF FIGURES}

28 to 32 Involution of the so-called fat cells of the bone marrow to 'Riesenzellen' in the plasma medium. White bone-marrow of a younger well-fed, fullgrown chicken in tissue culture from November 30 to December 1, 1915. Conservation: Formol. Osmium, Safranin stain. 
RHODA ERDMANN
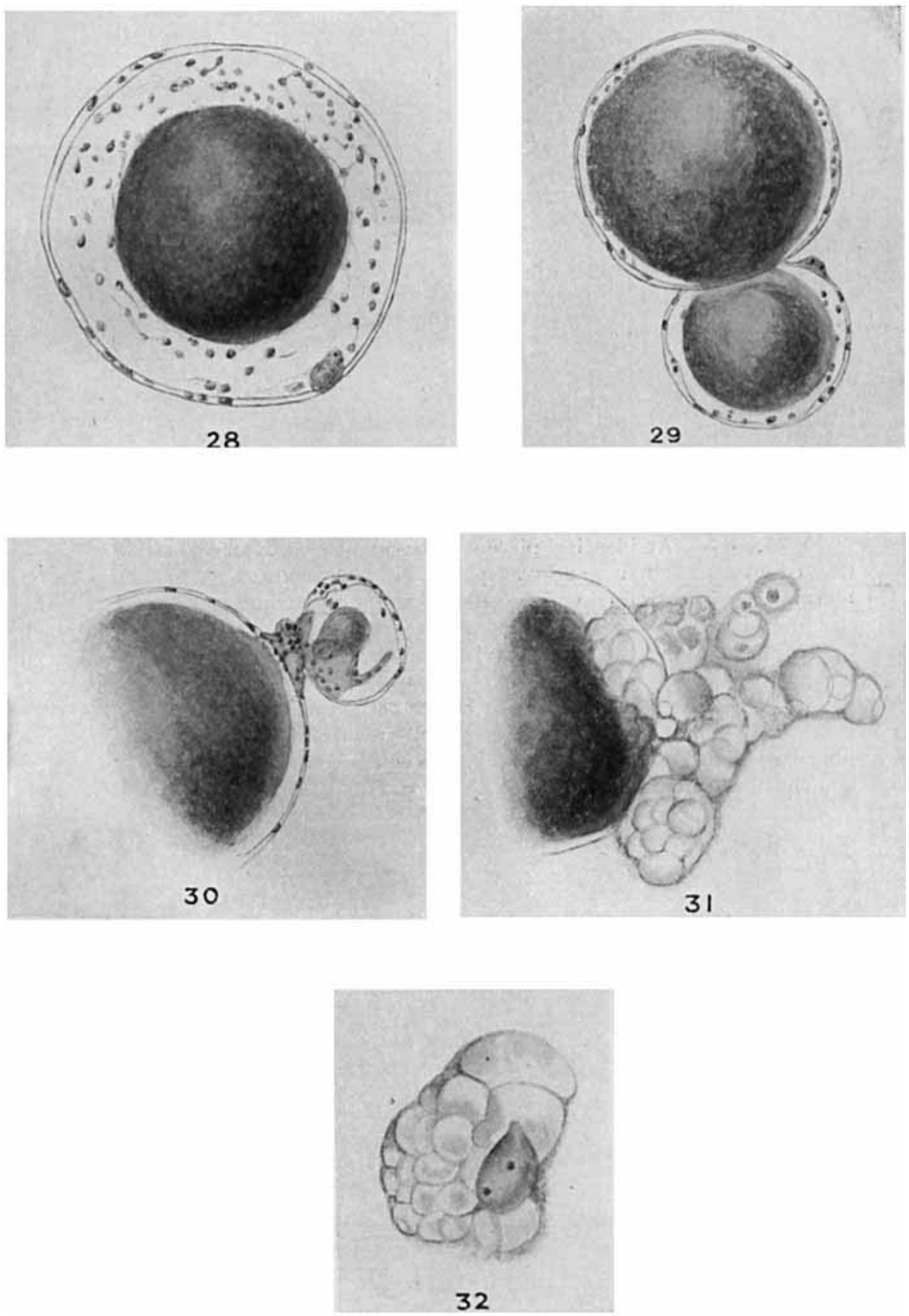


\section{PLATE 7}

\section{EXPLANATYON OF FIGURES}

33 and 34 White bone marrow from a younger full-grown, well-fed chicken in tissue culture at $38^{\circ} \mathrm{C}$. from February 29 to March 1, 1916. Foot's 'Riesenzellen' already present after one day's incubation.

35,36 and 37 An identical piece of bone-marrow, as described above, was extracted after three hours and transplanted in a new culture medium. The next morning, again extracted and transferred in a new medium. After eight hours the preparation was conserved and the cells nearest to the network studied. A cell, 35, of this preparation having migrated from the network, showing phagocytosis.

38 A cell of the network which begins to become disconnected.

39 to 42 White bone marrow from a full-grown chicken in tissue culture from February 22 to March 2,1916 , at $38^{\circ} \mathrm{C}$. Regressive changes of cells of the large mononuclear type or the myeolocytic type.

The cells figured on figures 33 to 38 were conserved with Orth's fluid, those on figures 38 to 42 with Schaudinn Sublimat Alcohol and stained with Giemsa stain. 
CHICKEN BONE MARROW IN PLASMA MEDIUM RHODA ERUMANN
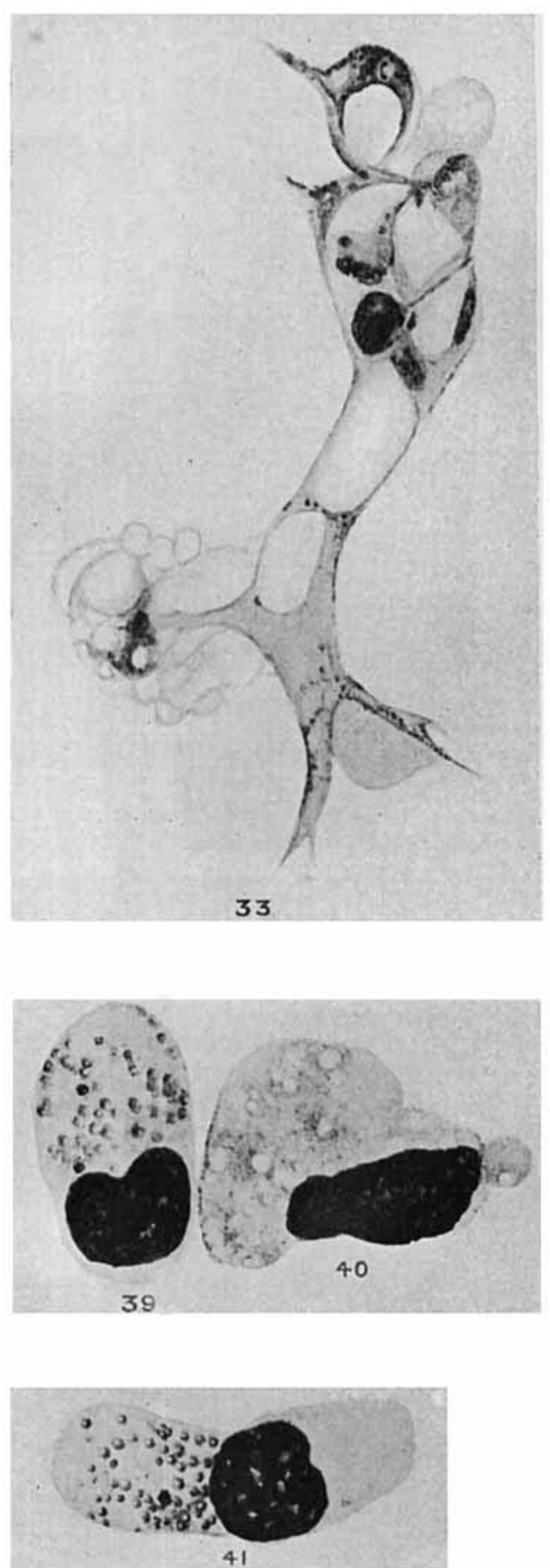

PLATE 7
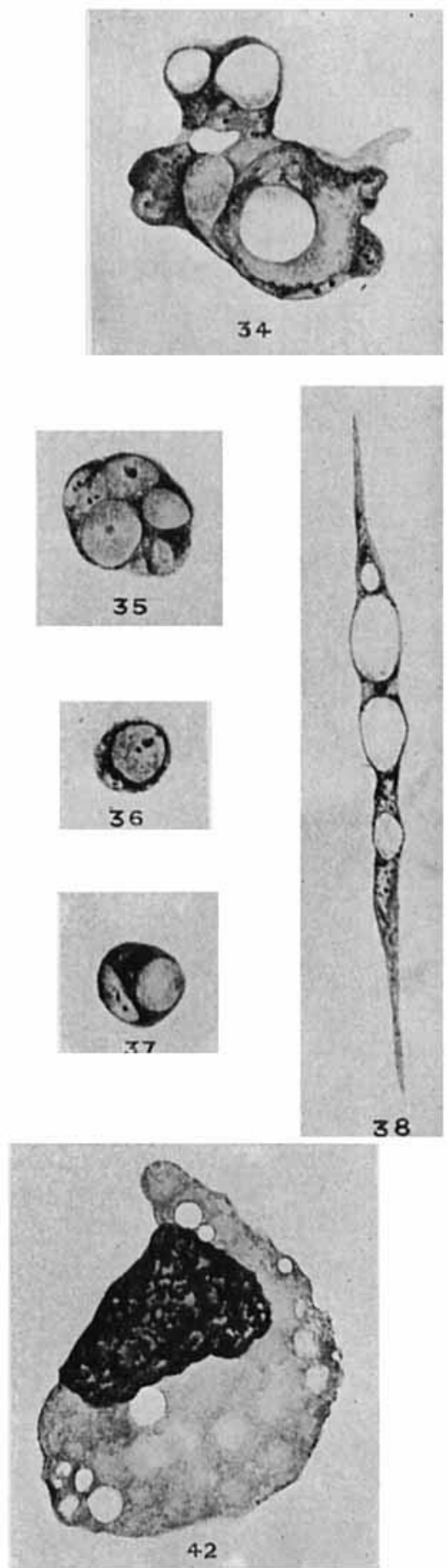


\section{PLATE 8}

EXPLANATION OF FIGURES

43 Emigrated cells after three hours incubation (mono- and poly-nuclear eosinophil leucocytes.

44 Emigrated cells after 24 hours incubation (mononuclear basophil cells) after the culture medium has been once changed after three hours.

Compare page 93-100 for detailed description. 

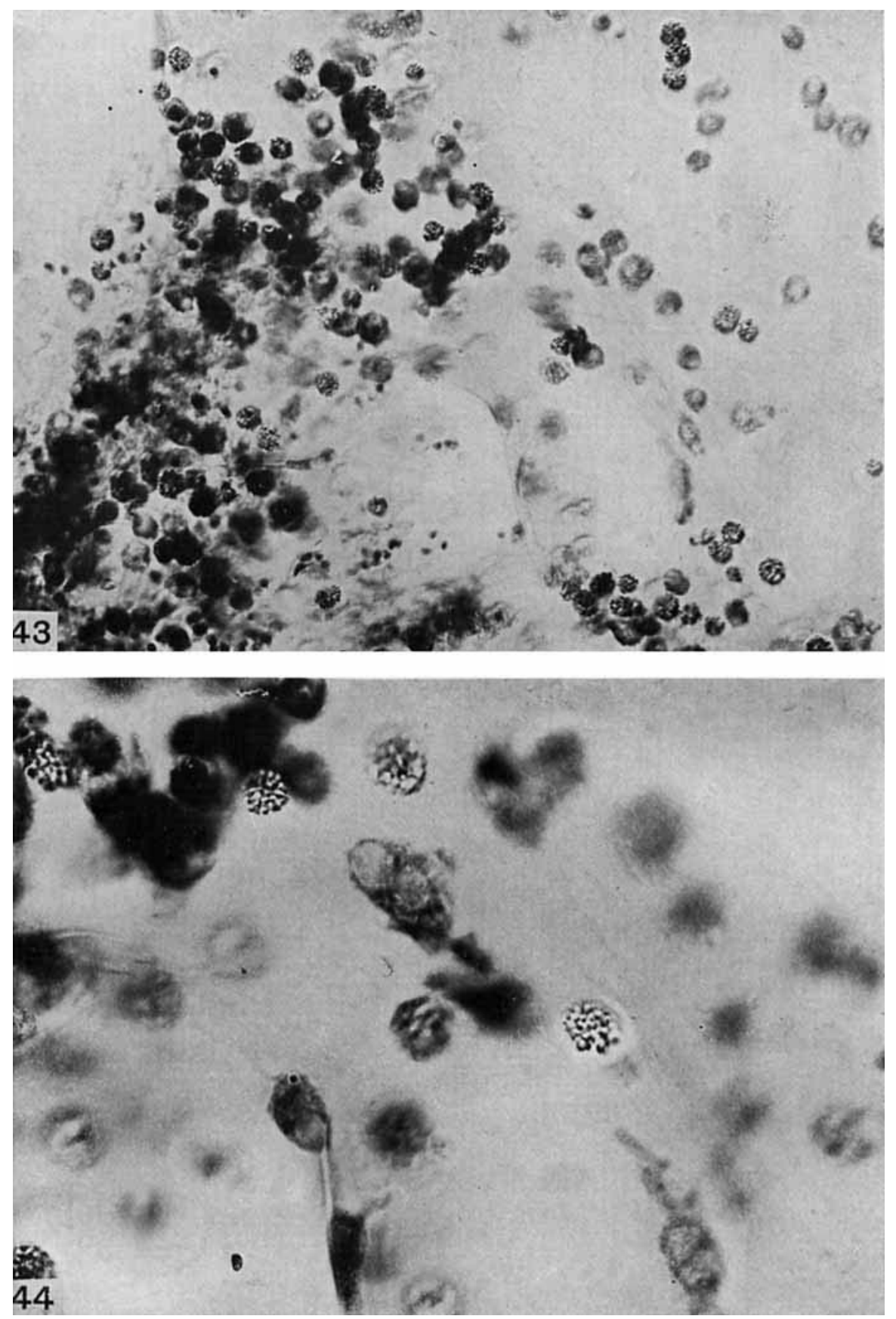
PLATE 9

EXPLANATION OF FIGURES

45 Involution of the fat cells after 24 hours incubation near to the implanted bone marrow particle.

46 Involution of the fat cells after 24 hours incubation. Cells near the periphery of the plasma clot. Compare figures 33 and 34, plate 7, from the same series of experiments. 
RHODA ERDMANN
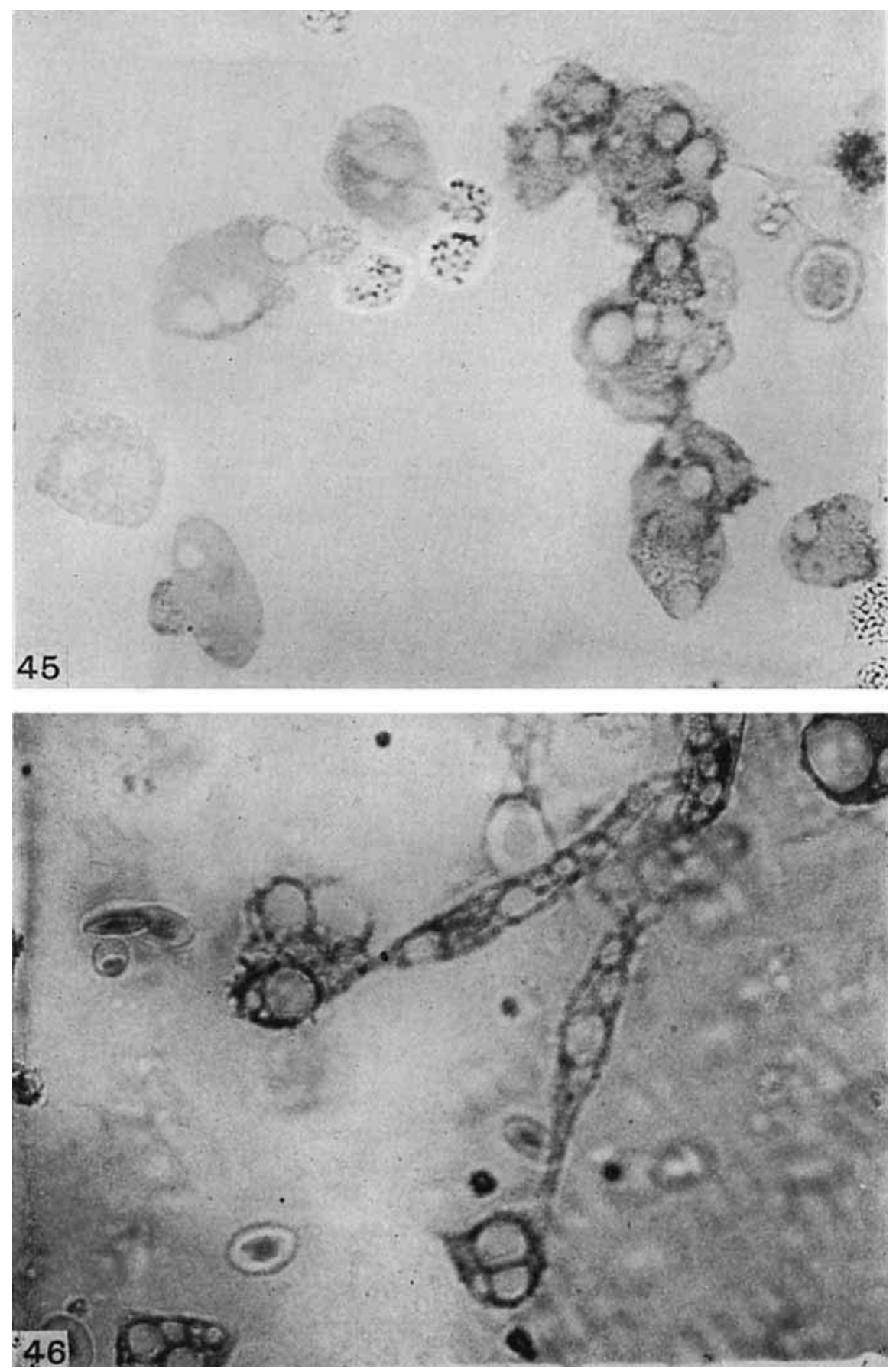